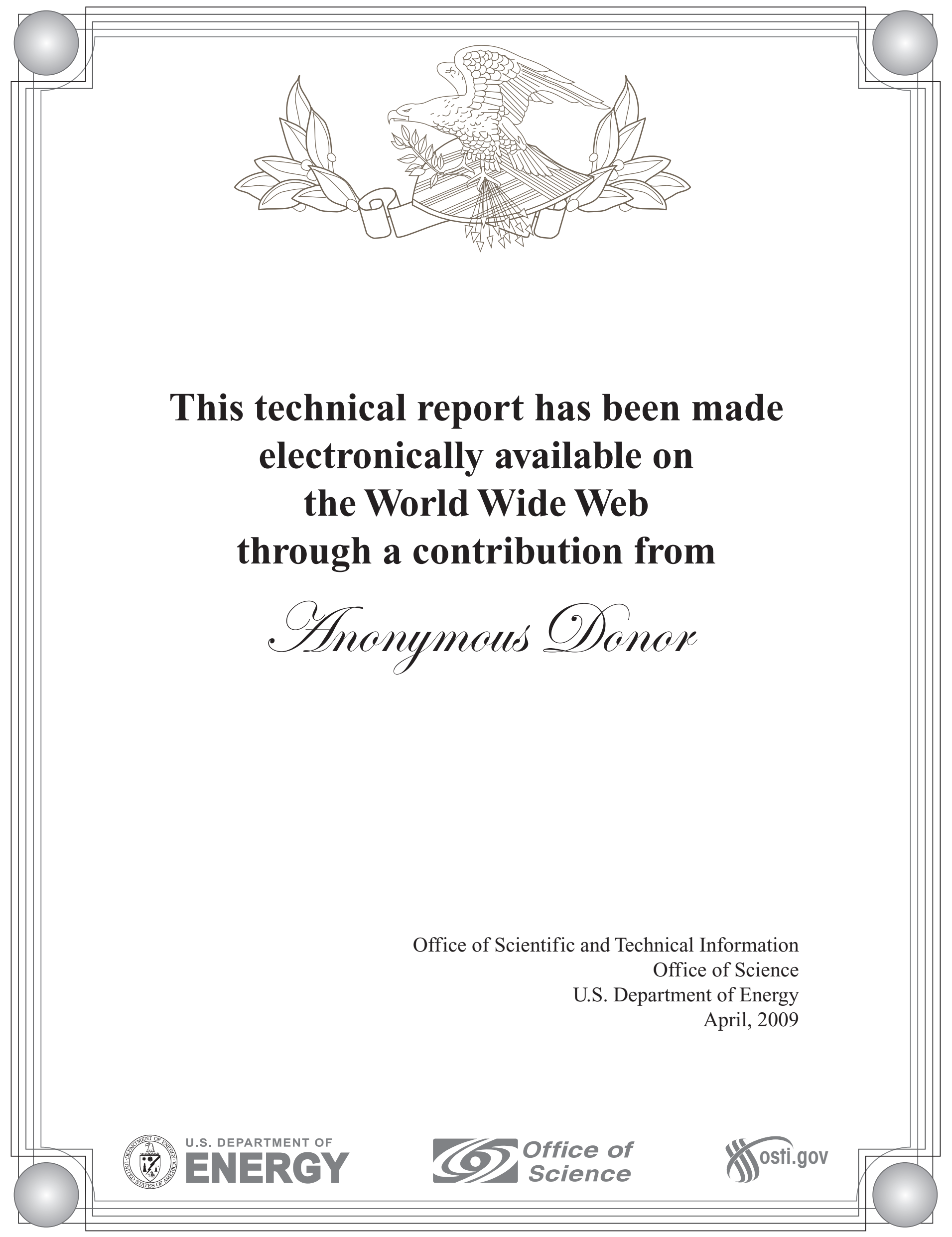




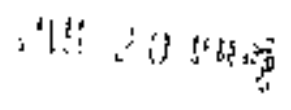

APED-4927
$65 A P E 4$
APRIL. 20, 1965
CLASS I

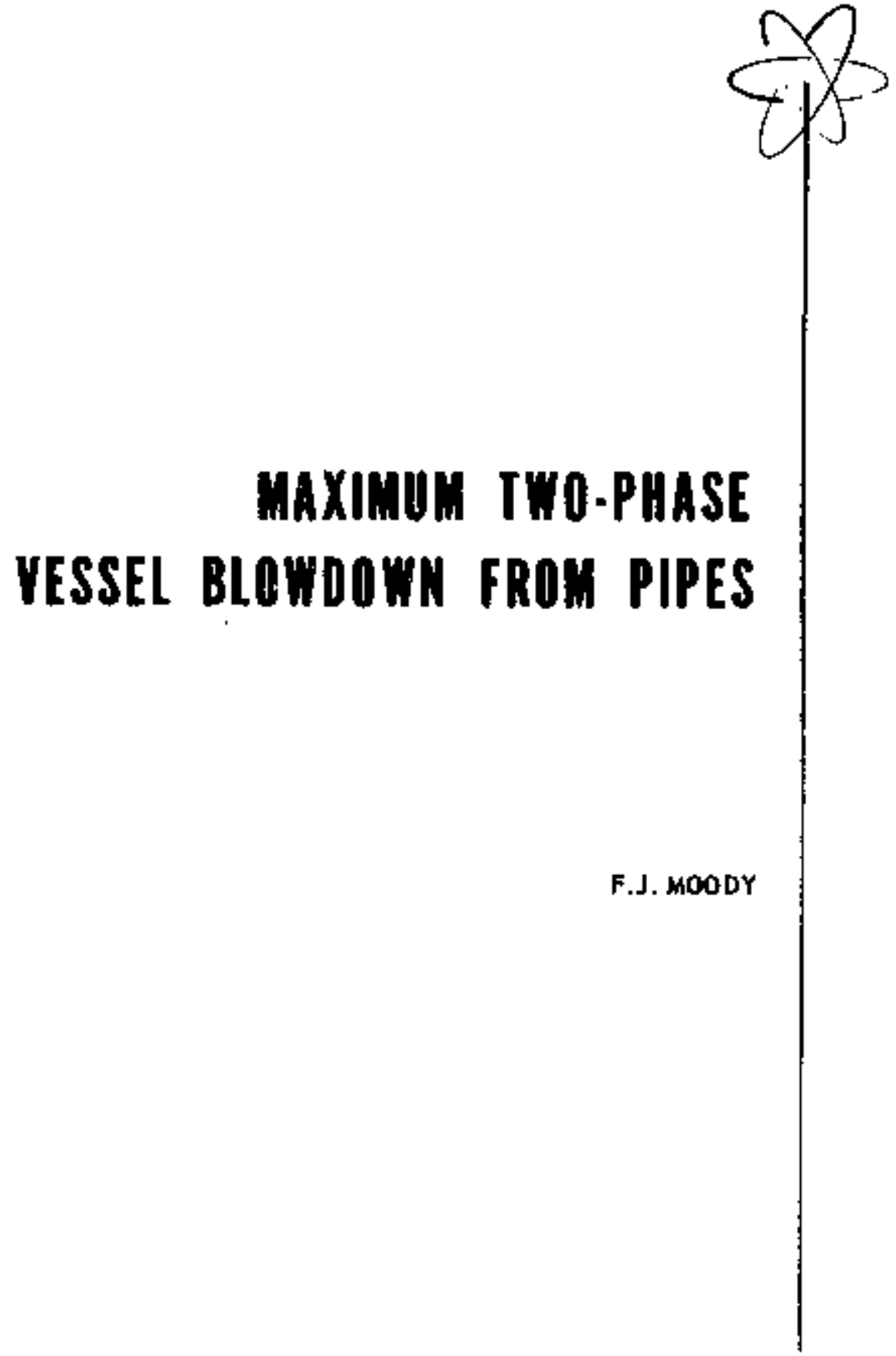

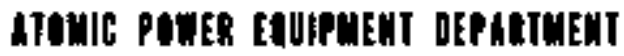
GENERAL ELECTRIG 


\section{DISCLAIMER}

This report was prepared as an account of work sponsored by an agency of the United States Government. Neither the United States Government nor any agency Thereof, nor any of their employees, makes any warranty, express or implied, or assumes any legal liability or responsibility for the accuracy, completeness, or usefulness of any information, apparatus, product, or process disclosed, or represents that its use would not infringe privately owned rights. Reference herein to any specific commercial product, process, or service by trade name, trademark, manufacturer, or otherwise does not necessarily constitute or imply its endorsement, recommendation, or favoring by the United States Government or any agency thereof. The views and opinions of authors expressed herein do not necessarily state or reflect those of the United States Government or any agency thereof. 


\section{DISCLAIMER}

Portions of this document may be illegible in electronic image products. Images are produced from the best available original document. 
MAXTMUM TWO-PHASE VESSEL

\title{
BLOWDOWN FROM PIPES
}

\author{
F. J, Moody
}

Approved:

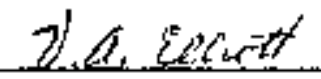

V. A. Ellioll. Manager

Reactor Plant and Systems Enyineerting

\section{GEAERAL BeLETHIG

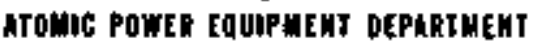 SHC JOSE, CALIFORHIA}




\section{DISCLAIMER OF RESPONSIBILITY}

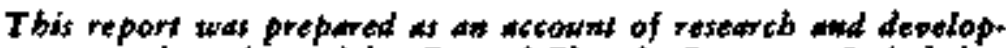
mase work performed by Genmal Electric Compewy. It is beisg made available by General Electric Company witbont consideration in the inserest of prowoting the tpred of recbsical buowlodze. Neither Geaeral Eloctric Compant wor tbe individual aubor:

A. Males aty warraty ar representation, expressed or insplied. witb respert to the accuracy, completesess, or wrefwhess of the

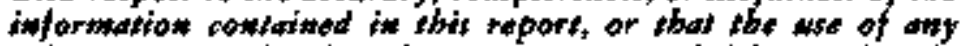
isformatios disclosed in this report moy wat infringe privately owned rights; or

B. Assumes any responribility for liability or damege wobicb may retwle from the use of aty information disclosed i* tbis report. 


\section{TABLE OF CONTENTS}

$\underline{\text { Page }}$

ABSTRACT 1 1-1

SECTION I

INTRODUCTION

$1-1$

SECTION II

THEORETICAL DEVELOPMENT

2-1

2. 1 Baste Equations for Two-Phase Pipe Flow

2-1

2. 2 Slip Ratio and a Conslstent Pipe Flow Model

2-3

2.3 Maximum Two-Phase Plpe Flow Rates

$2-4$

2. 4 Blowdown of Saturated Systems

$2-13$

SECTION III

RESULTS AND DISCUSSION

3-1

3. 1 Use of Ilustrations

3-1

3. 2 Comparison with Fauske's Data

3-1

3. 3 Correction for High Quality Flows

$3-5$

3.4 Comparison with Blowdown Tests

$3-8$

3.5 Estimation of Equiva Jent $\mathrm{TL} / \mathrm{D}$ for Bodega Bay Test 40

3-9

3.6 Comparison with Bodega Test 21

3-12

3. 7 Comparison with Bodega Test 16

$3-12$

3. 8 Comparison whth Humbolat Test 22

3-13

A PPENDIX A

NOMENCLATURE

$A-1$

REFERENCES

$-1-$

ACKNOWLEDGMENT

$-2-$ 


\section{LIST OF ILLUSTRATIONS}

Blowdown from 1250 psia Steam/Water Relerence System 


\title{
ABSTRACT
}

\begin{abstract}
A theoretical model is proposed for maximum two-phase flow from a constant area, adiabattc pipe with friction. Graphs are given for maximum steami water low rate in terms of pipe eeonletry and entrance stagnation properties. The proposed model ls used to obtain theoretical blowdown transients from saturated water systems initially at 1000, 1250 , and 2000 psia. Estimated plpe flow rates and bjowdown transients are comparod with steam/water data, keasonable agreement is shown.
\end{abstract}

\section{SECTION I}

\section{INTRODUCTION}

The subject of maximum two-phase flow has received increasing attention in the last 10 years. Faletti, (1) Fauske, (2) Moy, ${ }^{(3)}$ and $\mathrm{ZaJ}_{\text {oudek }}^{(4)}$ are amony investigators who have measured stem/water flows in long tubes of uniform area. Zaloufek ${ }^{(5)}$ later observed non-equilibrium effects in short tubes with $\mathrm{L} / \mathrm{D}<\mathrm{B}$. Recently, Fauske ${ }^{(B)}$ studied saturated water discharge through 0 . 25-inch-i. d. tubes up to 10. 0 Inch long. He concluded that steam/trater flows approached phase equilibrium at discharge when the tube length exceeded 3.0 inch. Non-equilibrium effecls predominated in shorter tubes,

Theoretical models by Fauske, ${ }^{(2)}$ Levy, ${ }^{(7)}$ and Mondy ${ }^{(8)}$ have predicted succesofully maximun steam/water flows for long tubes in ter ms of stalic pressure and stean quality at the discharye plaje. These models are based on ther modynamic equilibrium and a bumped-phase or anitular llow pattern with unequal phase valocitiess. Possible blowdown of high-pressure salurated liquti/vapor systems through pipes, valves, and orlfices plays an important role in nuclear reactor design. Time-dependent core environment and containment pressure are affected directly by the nature of blowdown. n..........

A large class of vessel blowdowns from pjpes cal be calculated with present maximum two-phase flow models by using pipe pressure drop correlalions as proposed by Martinelli and Netson ${ }^{(9)}$ or Levy. (10) A general blowdown solution is sought givtng: maximum flow rate in terms of vesgel stagnation properties and pipe geometry; and time-dependent pressure. mass, and energy in the vessel as a function of ptpe geometry.

The purpose of this wark is to:

1. Develop a moctel for maximum steam/waler pipe flow rale in terns of upstream stagnation properties ard pipe geometry;

2. Obtain theoretical blowdown Iransteits for saturated water recerence syslems with varlous pipe $L / D$ rathos and thow areas:

3. Compare maximum flow rates and estinated blowdown Iransients with dala. 


\section{SECTION II}

\section{THEORETICAL DEVELOPMENT}

\subsection{Bastc Equations for Two-Phase Pipe Flow}

The model shown in Flgure 2-1 includes these aseumptions: steady flow; annular flow without entrainment and liquid in contact with the wall; liquid and vapor in thermodynamic equilibrium at any section; unfform and linepar velocities of each phase; straight pipe with constant flow area and adiabatic walls; no shaft work.

Quality, $x$, rapor wold fraction, $\alpha$, and slip ratio, $K$, are deflned by

$$
\begin{aligned}
\mathrm{x} & =\frac{w_{g}}{w_{f}+w_{g}}=\frac{w_{g}}{W} ; \\
\sigma & =\frac{A_{g}}{A_{f}+A_{g}}=\frac{A_{g}}{A} ; \\
x & =\frac{u_{g}}{u_{f}} .
\end{aligned}
$$

Total flow rate per unit area, G, (abbreviated to "flow rate" in text) may be expressed as

$$
\mathrm{G}=\frac{W}{\mathrm{~A}}=\frac{a}{\mathrm{X}} \frac{\mathrm{u}_{\mathrm{g}}}{\mathrm{v}_{\mathrm{g}}}=\frac{1-\alpha}{1-\mathrm{X}} \frac{\mathrm{u}_{\mathrm{t}}}{\mathrm{v}_{\mathrm{f}}}
$$

Equations (1) through (4) lead to another expression for $a r$ :

$$
\alpha=\frac{1}{1+K\left(\frac{1-X}{X}\right) \frac{v_{f}}{v_{G}}} .
$$

Stagnation enthalpy. $h_{0}$, is constant through the pipe. Neglecting elevation terms,

$$
h_{0}=x\left(h_{y}+\frac{u_{g}^{2}}{2 g_{c} J}\right)+(1-x)\left(h_{f}+\frac{u_{f}^{2}}{2 g_{c} J}\right)+
$$



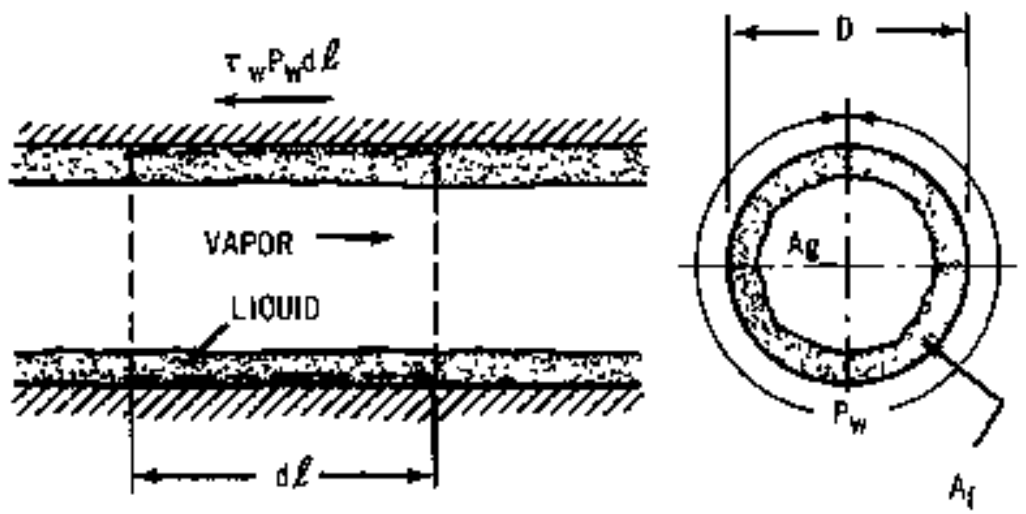

$\begin{array}{ll}w_{T} & w_{1} \cdot d H_{f} \\ w_{g} & w_{g}+d w_{g} \\ U_{f} & U_{f}+d U_{f} \\ U_{g} & U_{g} \cdot d u_{g} \\ P & P \cdot d P \\ X & X+d X \\ \alpha & \alpha+d \alpha \\ K & K+d K \\ t_{0} \text { CONST } & \\ G \text { CONST } & \end{array}$

F1gure 2-1. Incremental Pipe Section 
The two-phase momentw rate, $\Omega$, crosing any section is

$$
\Omega \quad-\left[X u_{\mathrm{F}}+(1-\mathrm{X}) \mathrm{u}_{\mathrm{f}}\right] \mathrm{GA} \text {. }
$$

The momentum equation for an incremental pipe section is therefore

$$
\frac{1}{B_{c}} d \Omega=-A d P-\tau_{w} P_{w} d t
$$

A formulation by Levy ${ }^{(10)}$ was used to express wall shear.

$$
\tau_{w}=\frac{f_{F(L S P)}}{2 g_{c}} v_{f}\left(\frac{1-x}{1-\alpha}\right)^{2} G^{2}
$$

Equation (9) is characterized by annular flow wilh llquid in contact with the wall. Levy found that this model accurately predicts pressure drop up to 0, 80 steam quality. Thereafter, better results are obtained from a vapor flow model. The term $f_{F(L S P)}$ is based on the liquid Reynold's number,

$$
\mathrm{R}_{\mathrm{eL}}=\frac{\mathrm{DG}}{\mu_{L}}\left(\frac{1-\mathrm{x}}{1-\alpha}\right)=\frac{\mathrm{DG}}{\mu_{L}}\left[1+x\left(\frac{1}{\mathrm{~K}} \frac{v_{\mathrm{G}}}{v_{f}}-1\right)\right] \text {. }
$$

\subsection{Slip Ratio and a Consistent Pipe Flow Model}

$\mathrm{Zivi}^{[11\}}$ showed that kinetic energy in a two-phase flow is minimum if the slip ralio is given by

$$
K=\left(\frac{v_{\mathrm{B}}}{v_{\mathrm{f}}}\right)^{1 / 3}
$$

He noted that minimum kinetic energy flow corresponds to minimum entrupy production, which characterizes a steady state thermodynants process.

The energy model proposed by Moody ${ }^{(8)}$ expresses $G$ (rom Equations (4) through (6) for constant $\mathrm{h}_{0}$ and Isentropic flow. Assuming $\mathrm{K}$ and $\mathrm{P}$ to be independent. Jjow rate is maximath when

$$
\left(\frac{\partial G}{\partial K}\right)_{P}=0
$$

and

$$
\left(\frac{\partial G}{\partial P}\right)_{K}=0
$$


Equation (12) gives Zivi ${ }^{\dagger} g$ ship ratio in Equation (11). The glip ratio $\left(v_{g} / v_{f}\right)^{1 / 3}$ tends to give sligitly higher theoretical two-phase flow rates. Theretore, the local pressure-dependent stip ratlo of Equation (11) $3 s$ assumed valld througbout the pipe. This assumption is consistent with the endrgy model ${ }^{(8)}$ which later is employed for maximum now rates.

\subsection{Maximum Two-Phace Ptpe Flow Rates}

The Mach number of subsonic gas tlow in a constant area, adiabatic pipe approaches unity in the direction of flow. (12) Gas flow rates are limited by choking (unity Mach number) at the discharge end. Corresponding behavior for steam/water flows has been observed experimentally. $(1,2,3,4,5)$

Figure 2-2 shows that the state of a two-phase system approaches maximum flow condition as static pressure drops. Points 1 and 4 represent entrance and exit states in a pipe. The process path between $I$ and 4 was obtained from Equations (4). (5), (6). and (11) for non-maximum flow at congtant $h_{0}$ and $G$. $G_{M 1}$, the maximum flow rate corresponding to state 1 is greater than $G$. But as pressure drops, tho fluid state approaches maximum now condition where $G$ and $G$ become identical. State 4 corresponds to the pipe ext where the flow chokes.

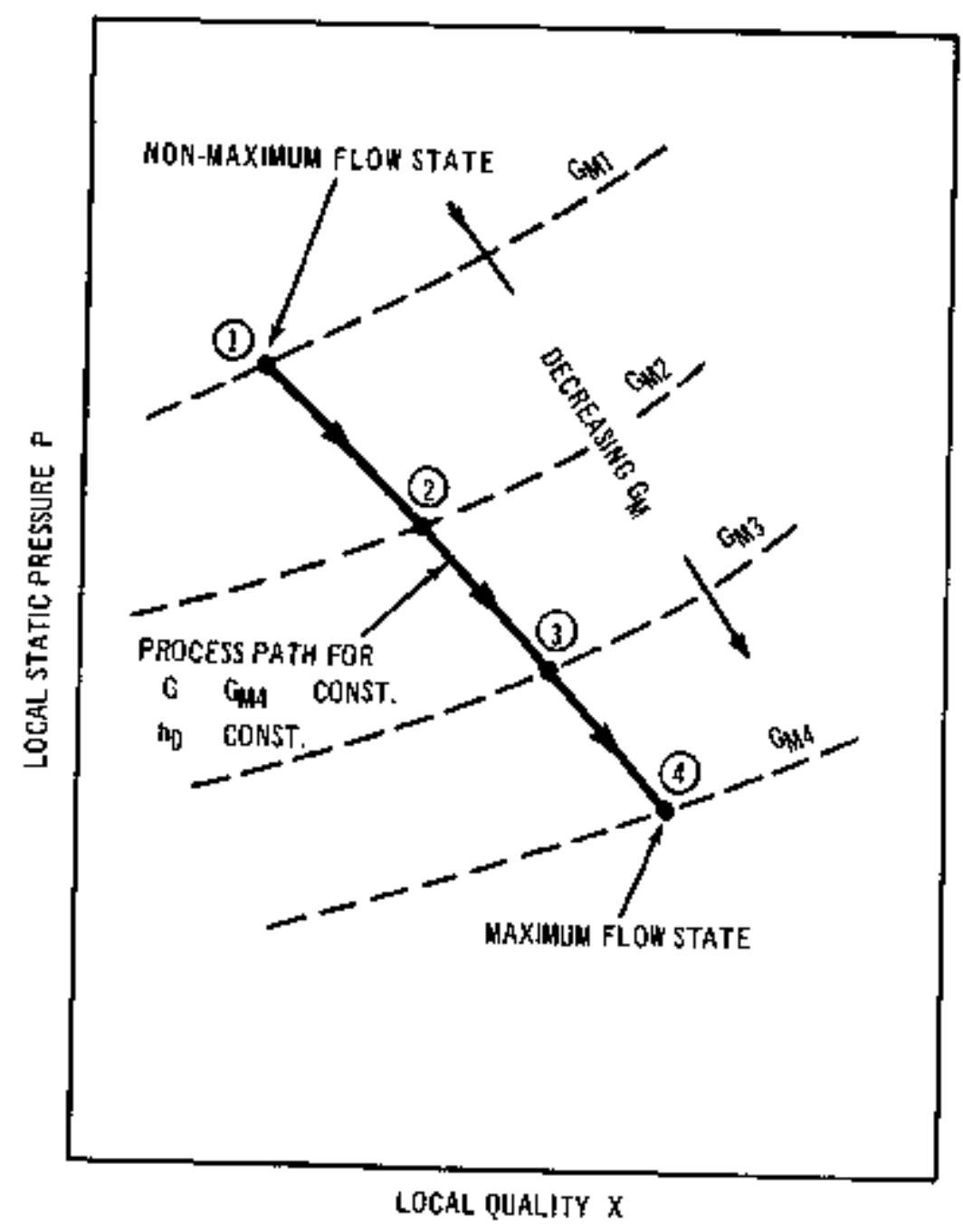

Fipure 2-2. Two-Phase Pipe Flow Process Path 
The energy and momentum equations, Equations (6) and (8), can be written in terms of $\mathrm{K}$ :

$$
\begin{aligned}
& G^{2} d f_{1}=-d P-f_{2} G^{2} d \\
& h_{0}=f_{3}+G^{2} f_{4}
\end{aligned}
$$

where

$$
\begin{aligned}
& f_{1}=\frac{J^{\prime}}{J} \frac{1}{g_{c}}\left[K(1-X) v_{f}+X v_{g}\right]\left(x+\frac{1-x}{K}\right) . \\
& f_{2} \quad=\frac{J^{\prime}}{J} \frac{P_{w}}{A} \frac{t_{E}(L S P)}{2 g_{c}} v_{f}\left[1+\left(\frac{1}{K} \frac{v_{v}}{v_{I}}-1\right) x\right]^{2}, \\
& f_{s}=b_{f}+x h_{f g} \text {, and } \\
& f_{4}=\frac{1}{2 g_{c} J}\left[K(1-X) v_{1}+X v_{B}\right]^{2}\left(x+\frac{1-x}{K^{2}}\right) .
\end{aligned}
$$

Since $K$ is given by Equation (11), Equations (16), (16). and (19) give $f_{1}, f_{3}$, and $f_{4}$ ln terma of $p$ and $\mathrm{X}$ only.

Substituting for $\mathrm{dr}_{1}$ in Equation (14),

$$
G^{2}\left[\left(\frac{\partial f_{1}}{\partial P}\right)_{X} d P+\left(\frac{\partial f_{1}}{\partial X}\right)_{p} d x\right]=-d P-f_{2} G^{2} d f \text {. }
$$

The values of $h_{0}$ and $G$ are constant throughout the pipe. Equation (15) provides a relationship between $P$ and $X$, typical of the process path in Figure 2-2 for whtch

$$
\frac{d X}{d P}=\frac{\left(\frac{\partial f_{3}}{\partial P}\right)_{x}+G^{2}\left(\frac{\partial f_{4}}{\partial P}\right)_{x}}{\left(\frac{\partial f_{3}}{\partial X}\right)_{P}+G^{2}\left(\frac{\partial f_{4}}{\partial X}\right)_{P}}
$$

The term $P_{Y} / A f_{F}$ (LSP) is replaced by $\bar{f} / D$ where $\bar{f}$ is an average Darcy friction factor in the pipe for the average liquid Reynold's number of Equation (10), and $D$ is the hydraulte diameter. 
Equation (20) can be written as

$$
\Gamma\left(P ; h_{0}, G\right) d P=\frac{\bar{I}}{D} d \ell
$$

where

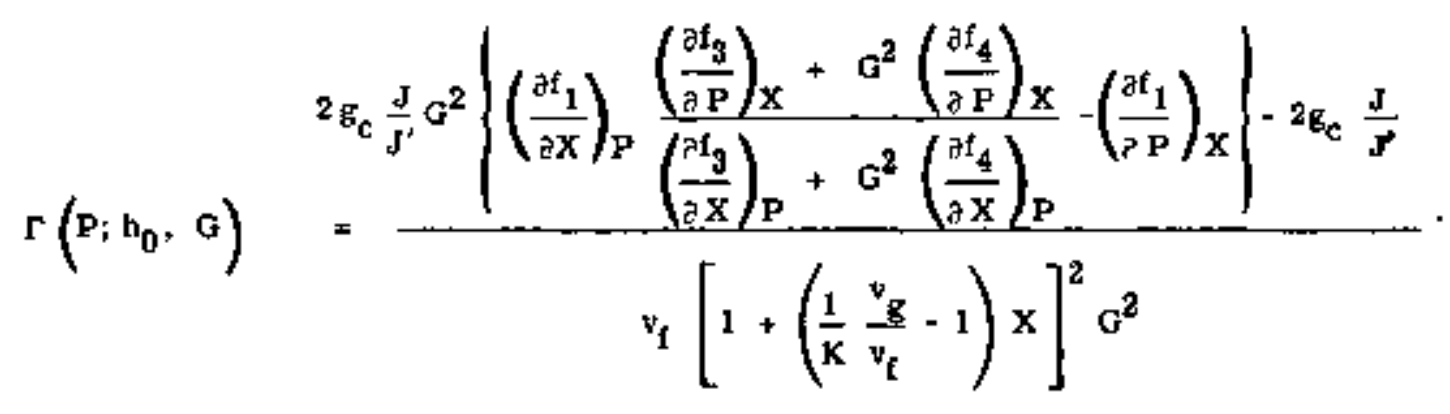

Referring to the exit plane (station 2 in Fifure $2-3$ ), $h_{0}$ and a maximum fow rate $G_{M}$ are sufticient to epecliy $P_{2}$ and $X_{2}$ from the energy model. $(8)$ Therefore, Equation (22) can be integrated from $P_{2}$ to some higher pressure $P_{1}$ at station 1 (Figure 2-3) giving

$$
\int_{P_{2}\left(h_{0^{+}} G_{M}\right)}^{P_{1}} \Gamma\left(P ; h_{0}, G_{M}\right) d P=\frac{\bar{T} L}{D}
$$

Known values of $P_{1}$. $h_{0}$ and $G_{M}$ uniquely determine $x_{1}$ from Equation (15). Stagnation pressure at station 1 is obtatned from the Idealized isentroplc entrance for which

$$
\begin{aligned}
& s_{0}=s_{1}=s_{f_{0}}+\frac{s_{f_{g_{0}}}}{h_{\mathrm{fg}_{0}}}\left(h_{0}-h_{f_{0}}\right) \text { and } \\
& s_{1}=s_{f_{1}}+x_{1} s_{\mathrm{fg}_{1}} .
\end{aligned}
$$

Equations (23) through (26) were programmed for machine calculation using balurated steanr 'waler properties. (19) Values of $P_{0}$ and $h_{0}$ cover saluration states from 25.0 to 2800 psia. Results are plotted in Figure 2-4 giving $G_{M}$ in either of the forms

$$
\begin{aligned}
& G_{M}\left(P_{0}, h_{0}, \frac{\bar{f} L}{D}\right)=0 \\
& G_{M}\left(P_{1}, h_{0}, \frac{\bar{I} L}{D}\right)=0
\end{aligned}
$$

for $\mathrm{f} \mathrm{L} / \mathrm{D}$ between 0.0 and 100 . 


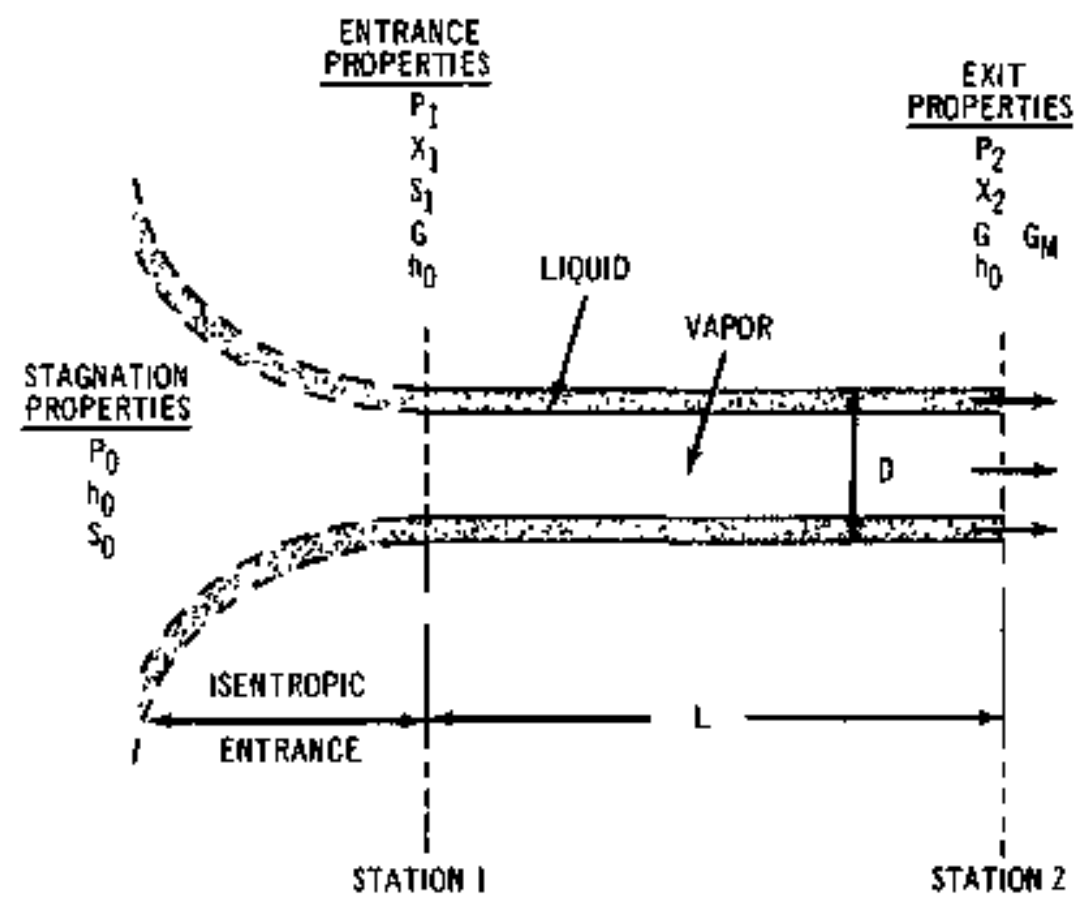

Ftgure 2-3, Pipe Maximuni Flow Model 

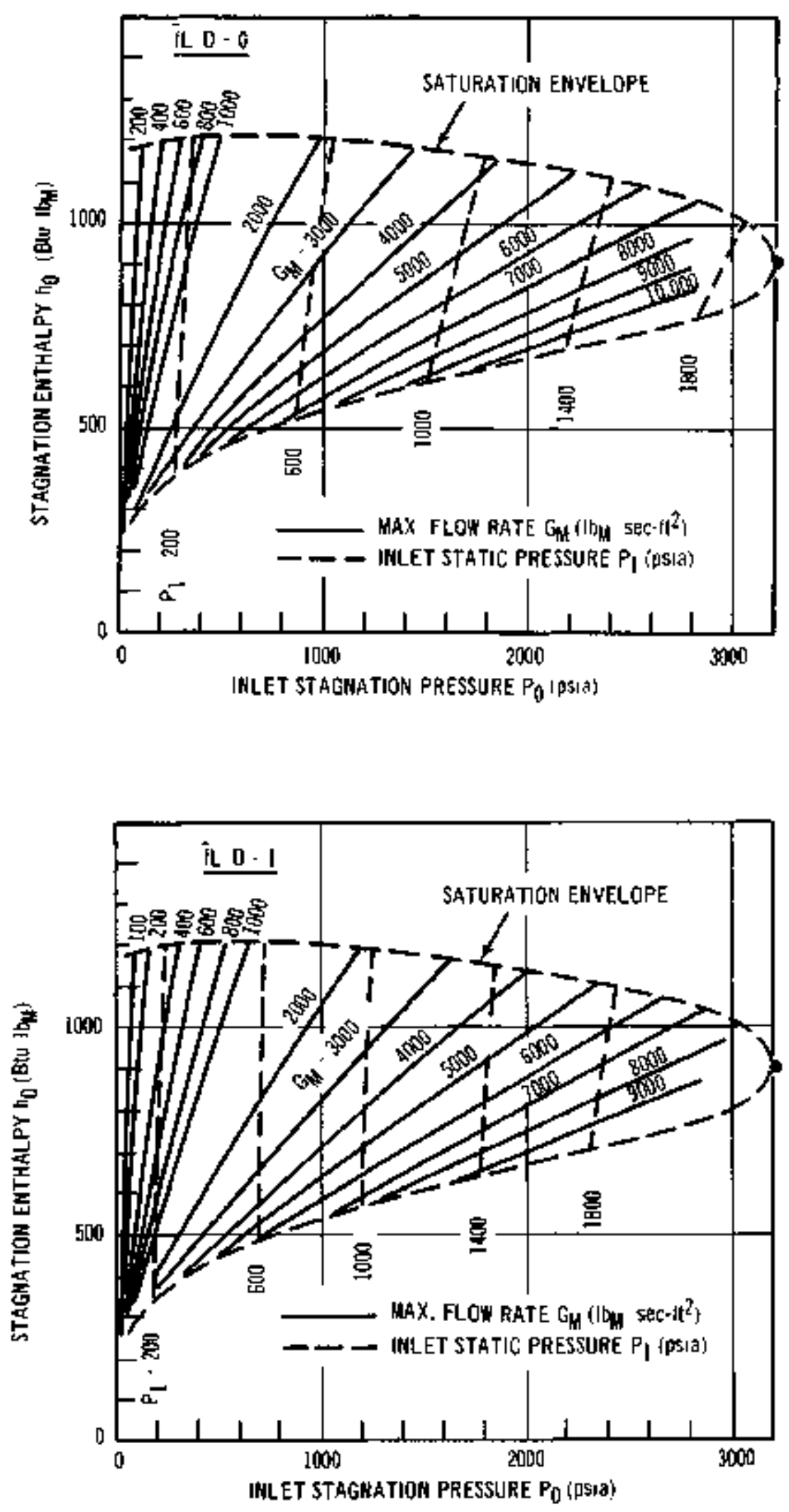

Figure 2-4. Pipe Maximum Steam/Water Discharge Rate 

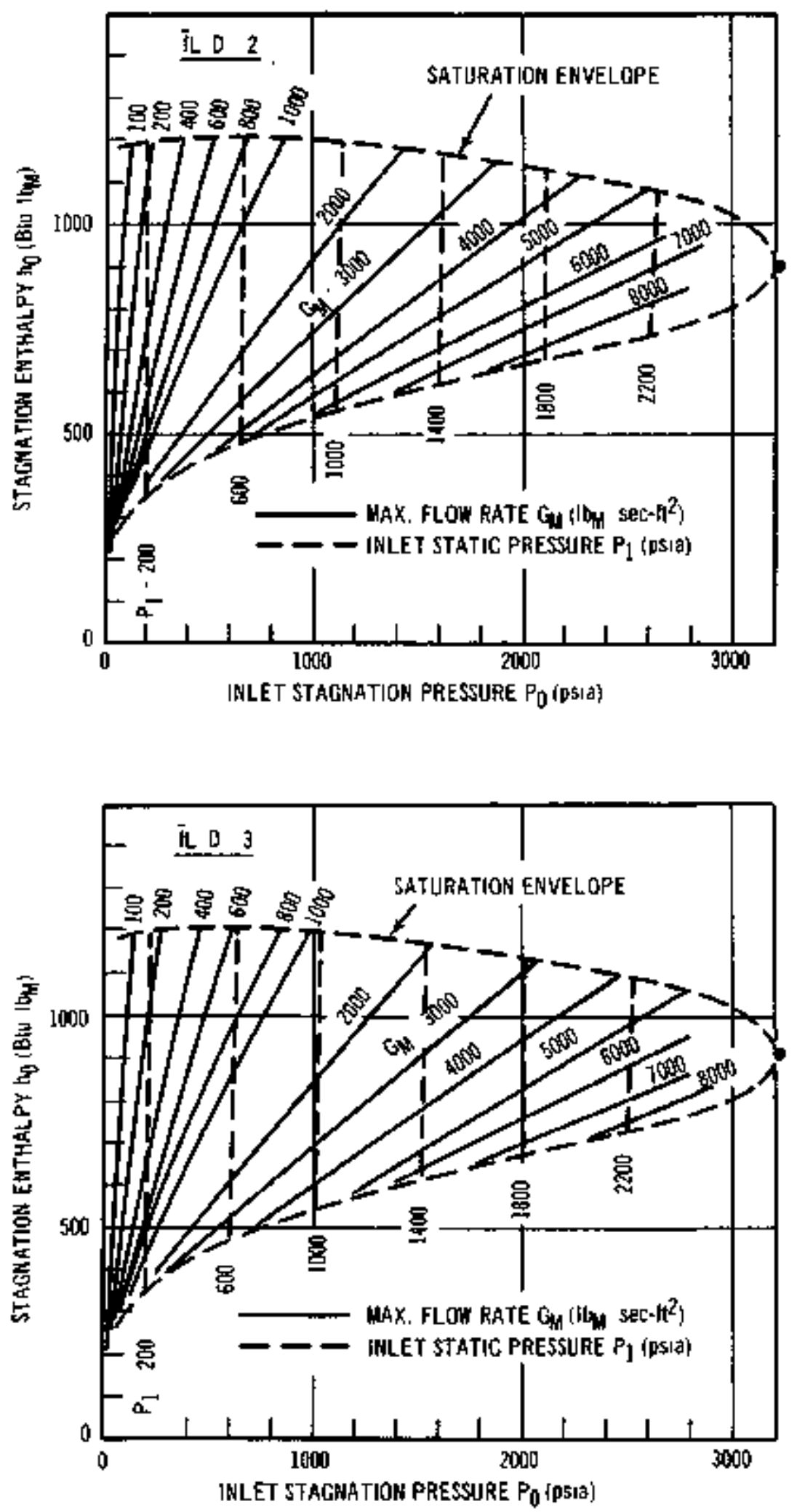

Flgure 2-4. Pipe Maximum Steam/Watar Discharge Rate 

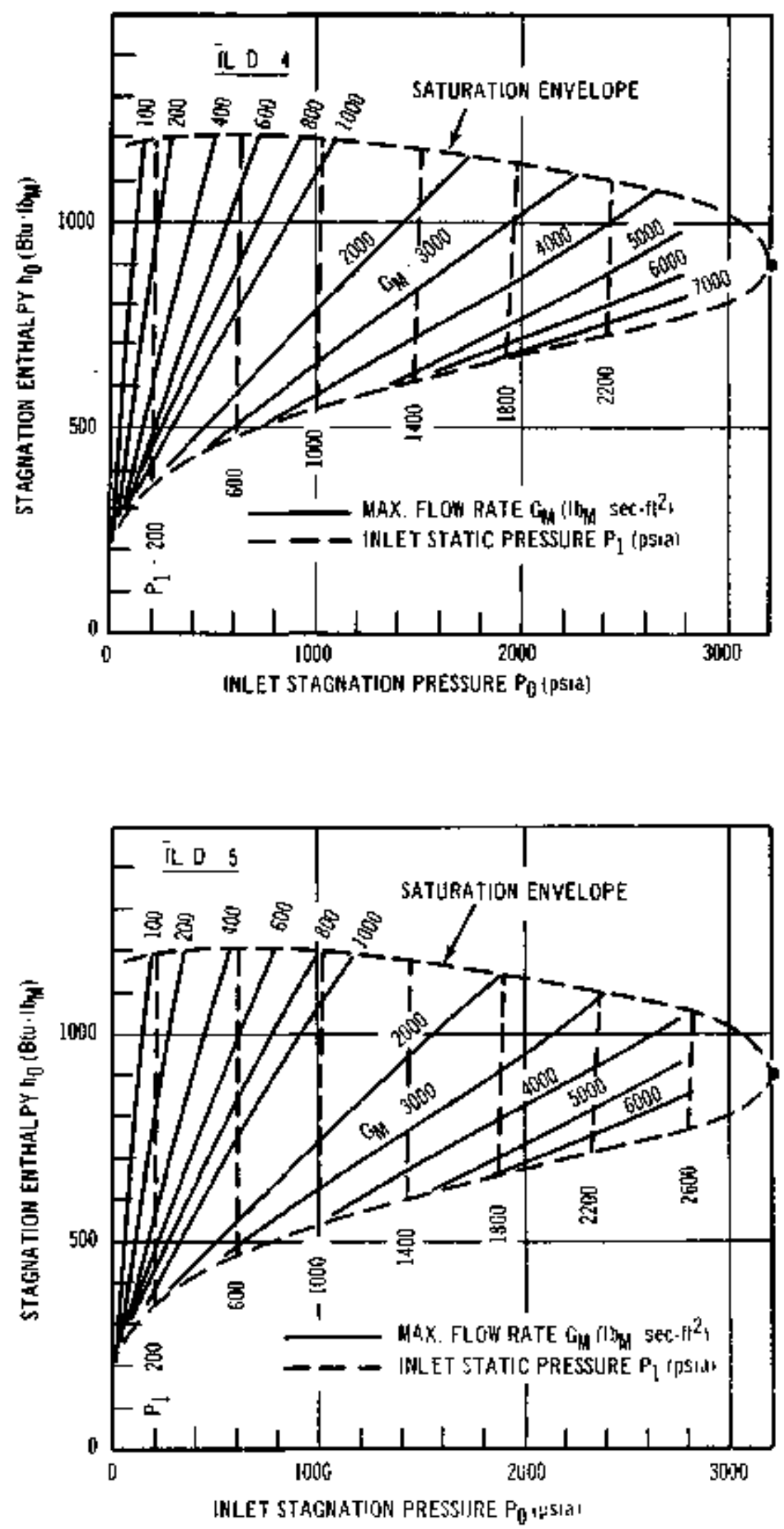

Figure 2-4. Pipe Maxtmum Steam/Waler Discharge Ratc 

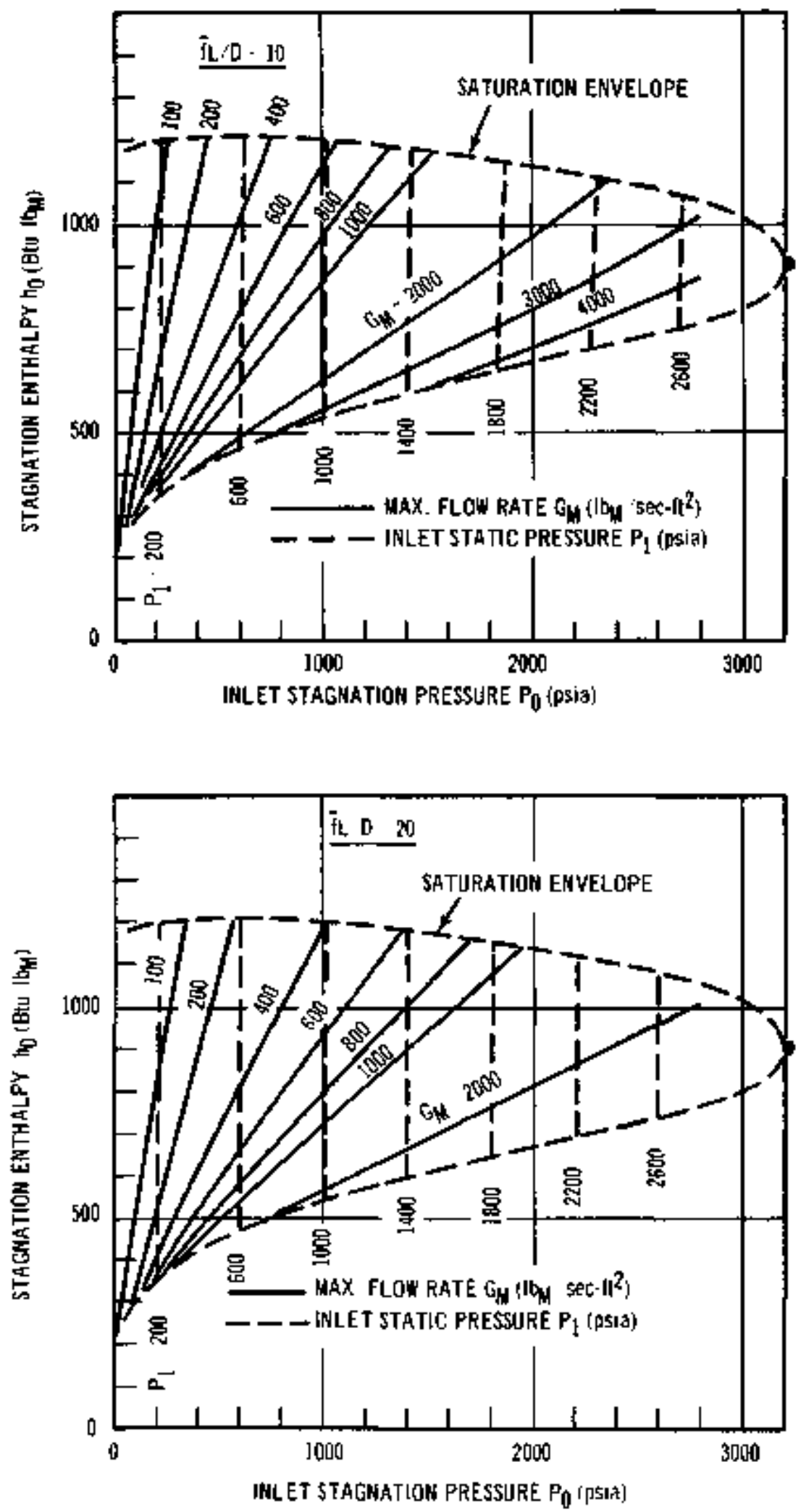

Figure 2-4. Pipe Maximum Steam/Water Discharge Fate 

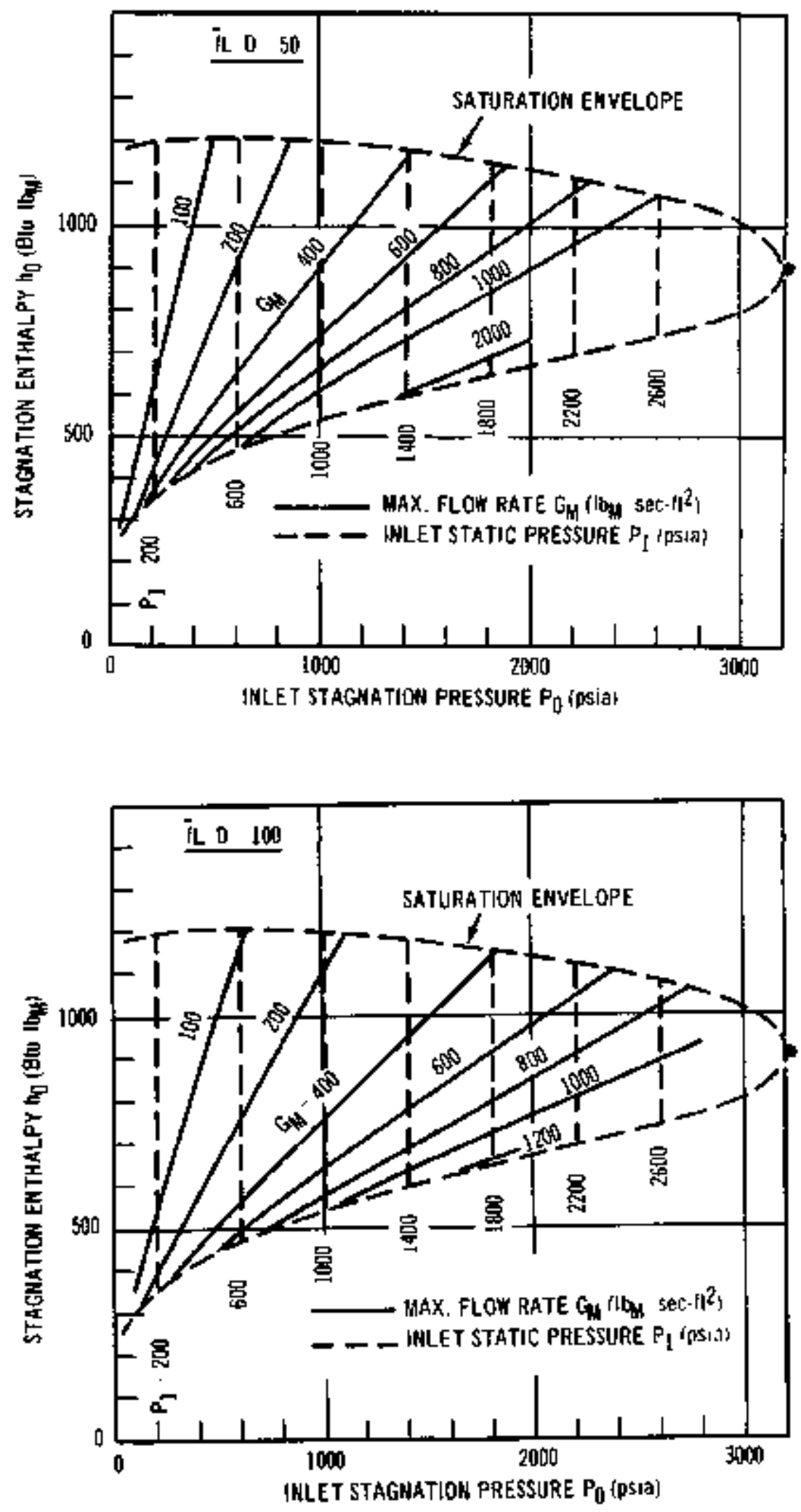

Figure 2-4. Pjpe Maximum Steam/Water Discharge Rate 
Fi sure 2-5. which relates $G_{M}, h_{0}, P_{2}$, and $X_{2}$, was constructed Irom the energy model ${ }^{(8)}$ and can Let used with Figure 2-4 to obtain $P_{2}$ and $X_{2}$ for maxibium steam/water plpe flows.

\subsection{Blowdown of Saturated Systems}

Fjpure 2-6 shows an adiabatic, constant volume system containht an equilibrium mixture of liquid/ vapor. Mass and energy escape through a singte pipe at rates $W$ and $h_{E} W$ respectively. The term $h_{E}$ is stagnation enthalpy of flutd in the immediale pipe neighborhood.

A state equition for saturated liquld/vapor is

$$
\frac{E}{M}=e_{f}+\frac{e_{f_{g}}}{v_{f_{g}}}\left(\frac{v}{M}-v_{f}\right) .
$$

No mass or enerby sources are considered; therefore, the following conservation equations apply.

$$
\begin{aligned}
& W+\frac{d M}{d t}=0 \\
& W h_{E}+\frac{d E}{d t}=0
\end{aligned}
$$

Differentiatsng Equatlon (29) and combining with Equations (30) and (31) to abtaln system pressure rate, it follows that

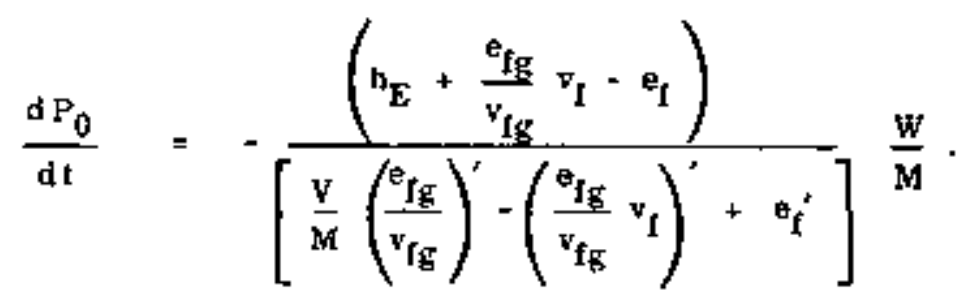

After substituting

$$
\begin{aligned}
W^{*} & =\frac{M}{M_{i}} \\
V & =v_{I} M_{i} \\
E^{*} & =\frac{G^{\prime}}{M_{i}} \frac{M}{M_{i}}
\end{aligned}
$$




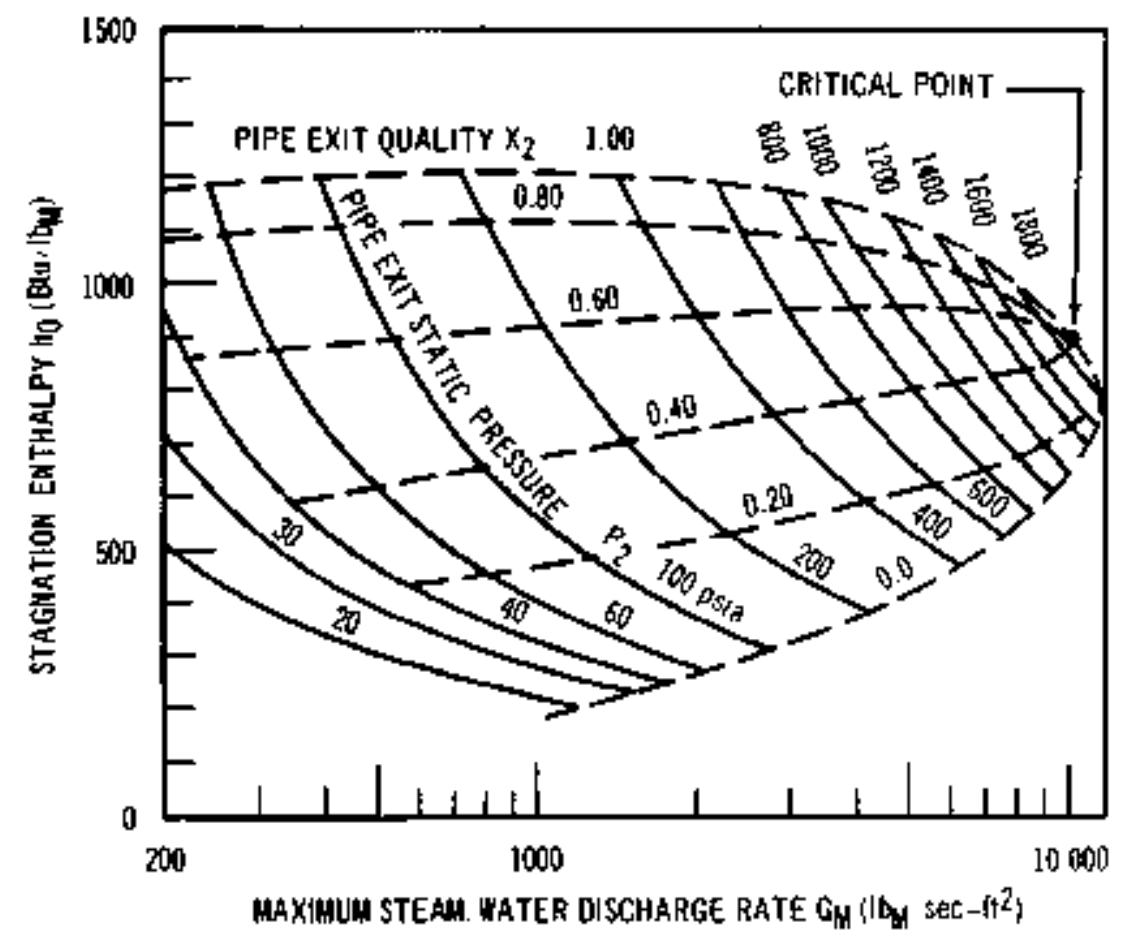

Figure 2-5. Pipe Exit Properlies for Maximum Sleam/Water Discharge 


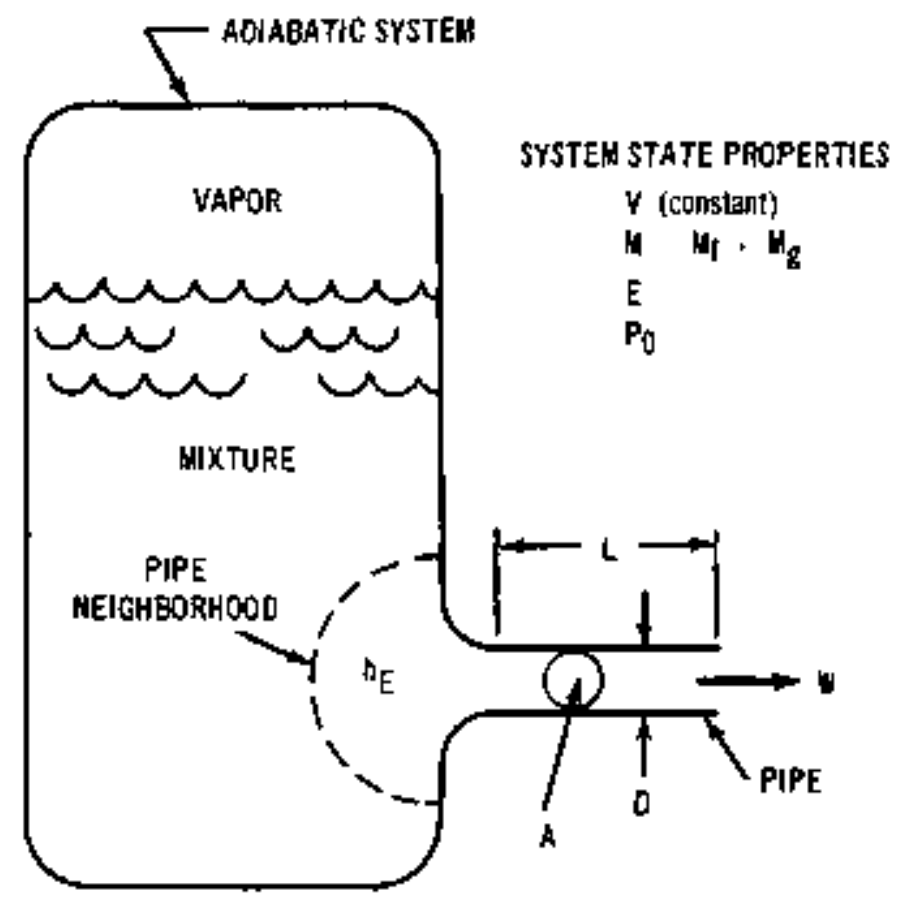

Figure 2-6, Saturated System Blowdown Mode! 


$$
t^{*} \quad=\frac{A}{M_{i}} t
$$

Equations (30), (31), and (32) become

$$
\begin{aligned}
& \frac{d M^{*}}{d t^{*}}=-G \\
& \frac{d E^{*}}{d t^{*}}=-\frac{h_{E}}{e_{j}} \\
& \frac{d P_{0}}{d t^{*}}=-\frac{\left(h_{E}+\frac{v_{f g}}{v_{f g}} v_{f}-e_{f}\right) G}{\left[\frac{v_{l}}{M^{*}}\left(\frac{e_{f g}}{v_{f g}}\right)-\left(\frac{e_{f g}}{v_{f g}} v_{f}^{\prime}+e_{f}^{\prime}\right] M^{*}\right.}
\end{aligned}
$$

Equation (27) is the form used to express $G$, where $h_{E}=h_{0}$.

The value of $h_{E}$ depends on $P_{0}$ and liqutd/vapor action in the system. Three characteristic blowdowns are considered:

1. Saturated liquid blowdown characterized by

$$
h_{E} \quad-h_{f}\left(P_{0}\right) \text {. }
$$

2. Homogenlzed mixture blowdown characterized by

$$
h_{E}=h_{f}\left(P_{0}\right)+\frac{h_{f g}\left(P_{0}\right)}{v_{f g}\left(P_{0}\right)}\left[\frac{v_{j}}{M^{*}}-v_{f}\left(P_{0}\right)\right] .
$$

3. Saturated vapor bloळdown characterized by

$$
\mathbf{h}_{\mathbf{E}} \quad=\mathbf{h}_{\mathrm{B}}\left(\mathrm{P}_{0}\right)
$$

Equations ( 88$)$, (39), and (40) were integrated numerically to express $P_{0^{*}} M^{*}$, and $E^{*}$ il terms of t*. Results are shown in Figure $2-7$ for three steam/water reference systems initially flled whth saturated water at 1000,1250 , and 2000 psia. Saturated liquid, mixture, and vapor blowdowns are included for each reference system. Curves for $\bar{T} \mathrm{~L} / \mathrm{D}$ values from 0.0 to 100 are inchuded. Liquid blowdown curves were obtained by taking $h_{E}=h_{f}\left(P_{0}\right)$ until all liquid was gone, leaving only saturated vapor in the system. Thereafter, blowdown was completed with $h_{E}=h_{g}\left(P_{0}\right)$. Liquid disappeared from the 1000 , 1250 , and 2000 psia reference systems at $P_{0}$ values of 660 , 770, and 1150 psia respectively. 

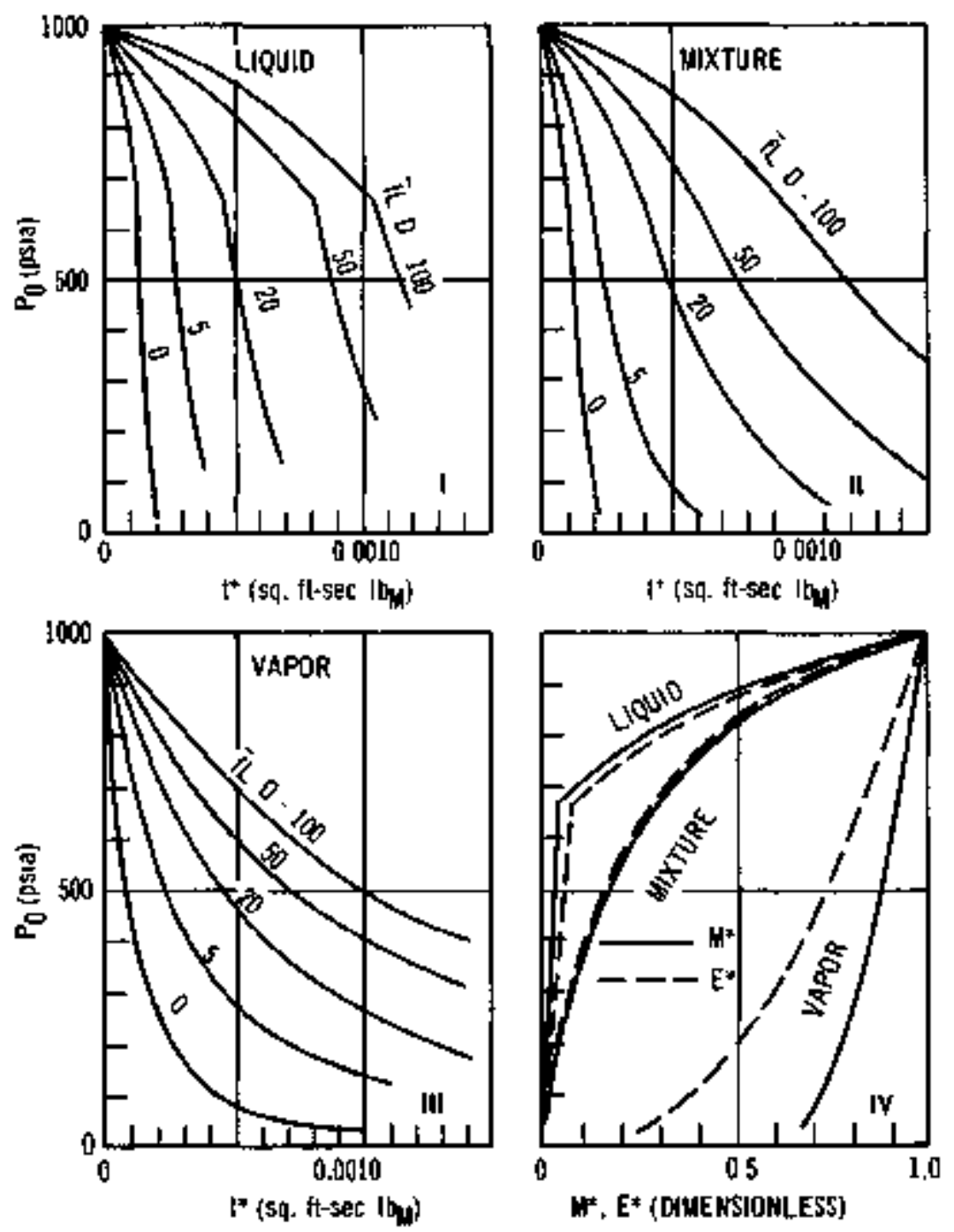

Fjgure 2-7. Blowdown Irom 1000 psia Steam/Water Reterence System 

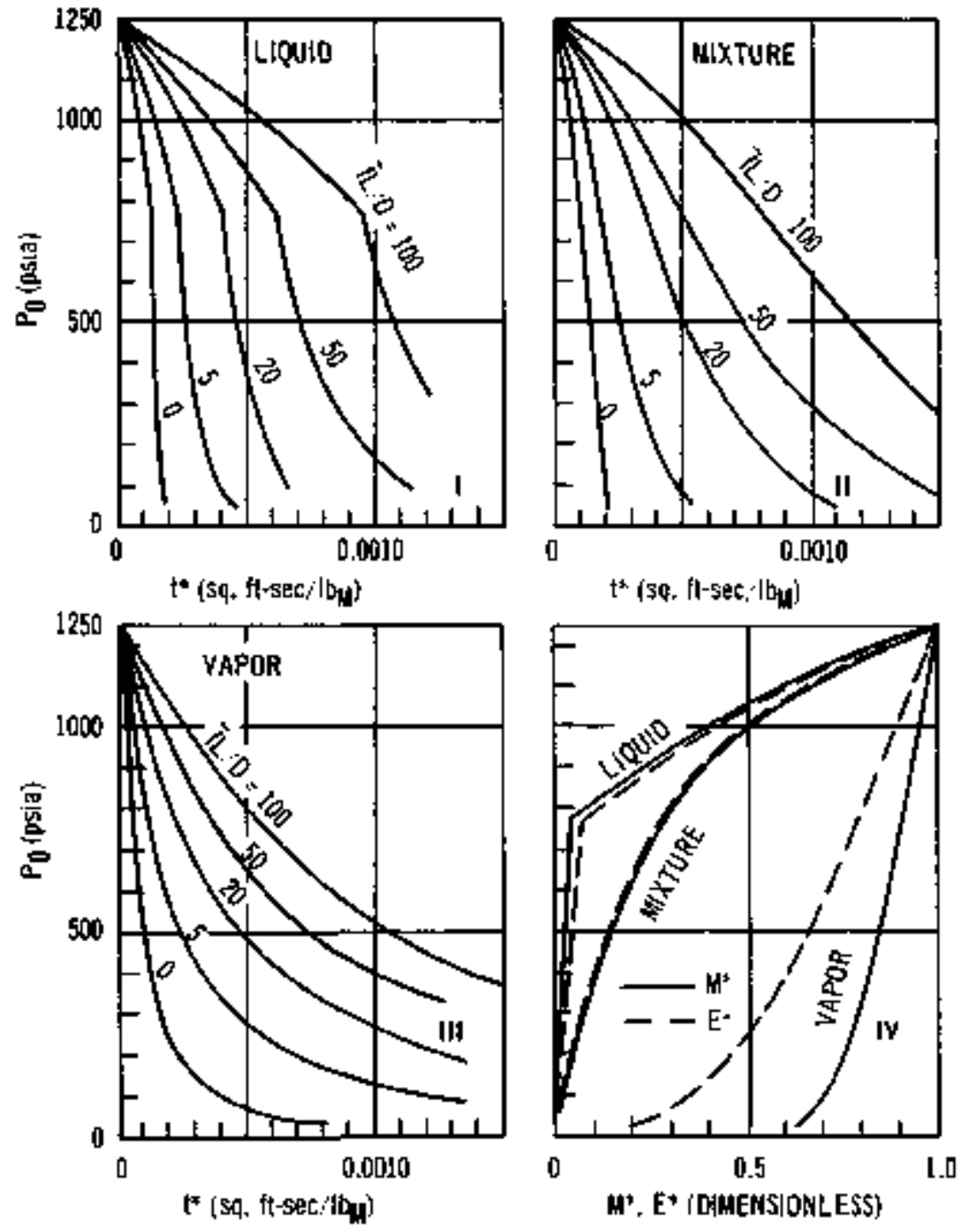

Flgure 2-7. Blowdown from 1250 psia Steam/Water Reference System 

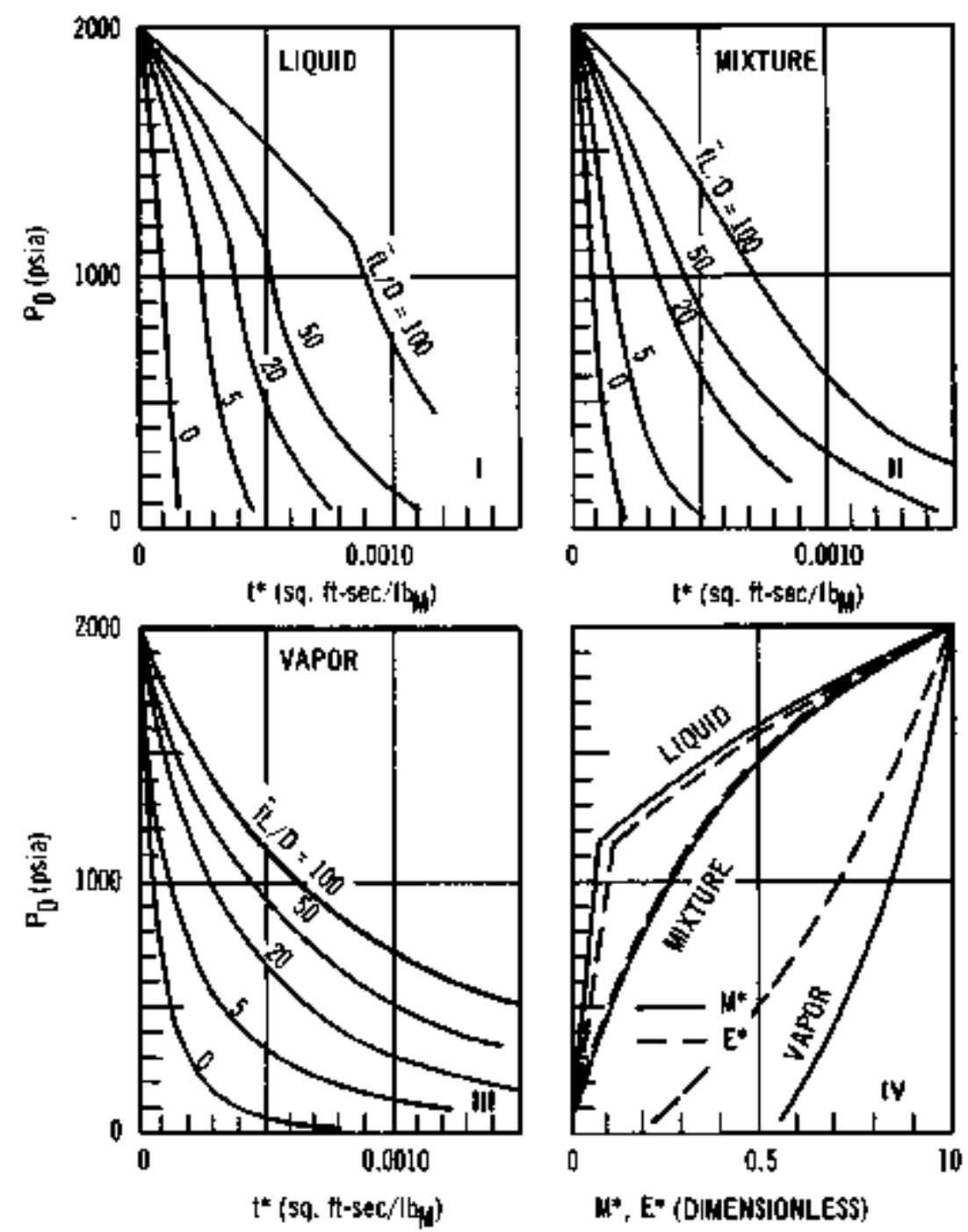

Figure 2-7. Blowdown from 2000 psia Steam/Water Reference System 


\section{SECTION III}

\section{RESULTS AND DISCUSSION}

\section{1 Use of Illustrations}

Maximum discharge rates of saturated steam/water from constant area pipes can be estimated Irom Flgure 2-4 when values for $P_{0}, h_{0}$, and $\bar{f} L / D$ are known. Friction factor changes slowly with Reynoldt $B$ number. An approximate $R_{e L}$ can be computed from Equation (10) based ou estimated $G_{M}$ and pipe inlet conditions. An average $\bar{f}$ can be obtained from standard charts. (14) Using $G_{M}$ obtained from Figure 2-4, and $h_{0}$, Figure 2-5 can be used to estimate pressure at the discharge plane, $P_{2}$. If $P_{2}$ excesds recetver pressure, maximum flow oceurs. However, if receiver pressure exceeds $\mathrm{P}_{2}$, maximum flow does not occur, and Figure 2-4 is not valid. An Improved solutlon for $G_{M}$ can be obtained by evaluating $R_{e l}$ at an average pressure in the pipe.

Stenm/water discharge is often related to pipes with local turns, valves, area changes. etc. Unfortunately, the two-phase pressure logs at a local restriction is clfficult to represent aceurately in terms of equivalent pipe length as to often done in single-phase flow. This technique mat be employed in the present model for first approximations. However, it may be necessary to examtne all upstream area restrictions to estimate the actual location where flow chokes.

Flgure 2-7 can be used to estimate system pressure, mass, and energy at various times during a vessel blowdown. The value of $P_{0}$ is shown as a function of $t^{*}$ in Graphs $I$, II, and III. Graph IV gives $M^{*}$ and $E^{*}$ in terms of $P_{0}$ for liquid, mixture, and vapor blowdowne. Values of t* may be tound from Graph I, II, or tIt for corresponding $M^{*}, E^{*}$, and $P_{0}$ in Graph IV.

Liquid blowdown corresponds to mass loss from a low point on the system if vapor entrainment is minor. Mlxture blowdown applles to rapld mass loss from the syslem during which vapor forms taster than it can separate from the remaining liquid. Vapor blowdown implies flow from a high point on the syatem, slow enough for internal vapor separation without liquid entrainment.

Systems in practice usually are not initially filled with saturated water, However, Flgure 2-7 may be used to estimate time-dependent $\mathbf{P}_{0}, \mathrm{M}^{*}$, and $\mathrm{E}^{*}$ for saturated systems containing some vapor by excluding the inttial vapor volume.

\subsection{Comparison with Fauske's Data}

Flgure 3-1 (a) through (e) compares calculations with the present model with Fauske's data for maximum steam/water discharge rates from straight pipes, ${ }^{(2)}$ Static pressure taps were at one diameter, $B, 12,24,36$, and 48 inches from the discharge end. Fauske obtained discharge plane pressure by extrapolating static pressure readings. His exit quality was calculated from the energy equation with a homogenęous kinetic fnẹrgy tẹrm. This calculation was reversed to obtain actual test values of stagnation enthatpy for plotting data in Figure 3-1 (a) through (e). Static pregsure at the first tap 48 inches upstream from discharge corresponds to $\mathrm{P}_{1}$ in the present model. An average $\mathrm{R}_{\mathrm{eL}}$ for the range of pipe low data is about $10^{6}$. Thereiore, $\overline{\mathrm{T}} \approx 0,01$ for smooth pipes was used for all comparisons with Fauske's date. 


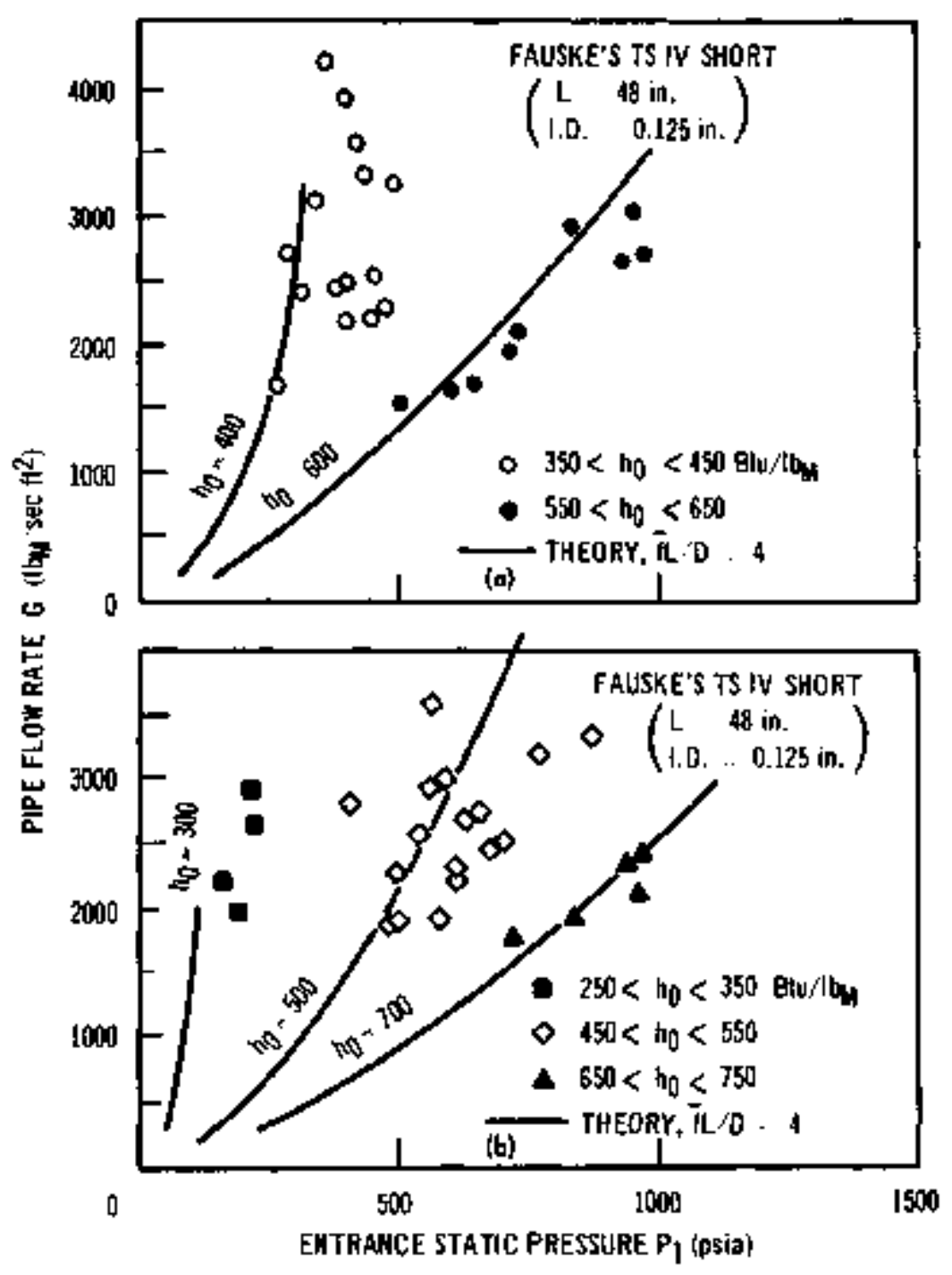

Figure 3-1. Comparison with Fauske's Maximum Steam/Water Pipe Flow Data 


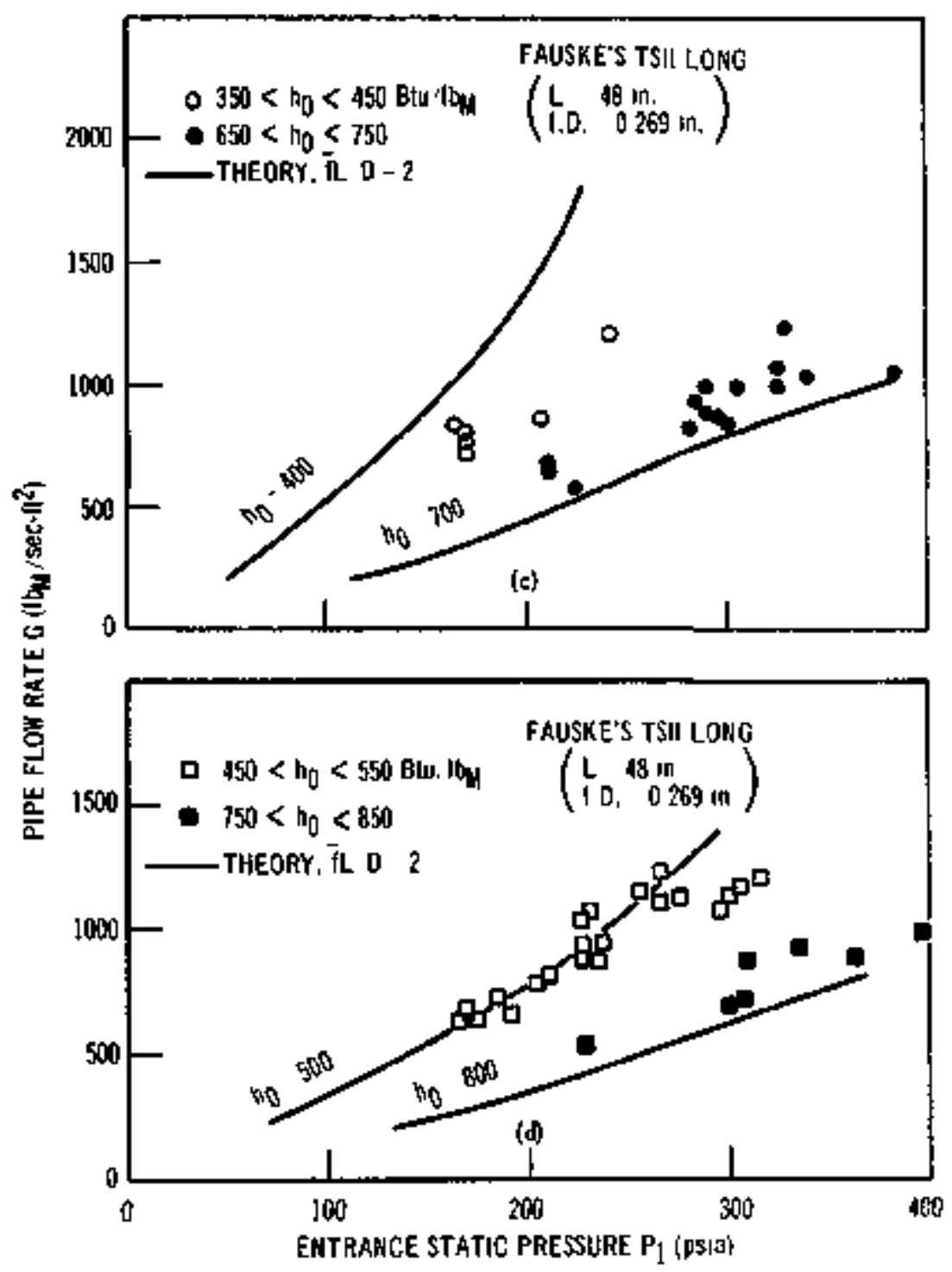

Fygure 3-1. Comparison with Fauske's Maxımum \$team. Water Pıpe Flow Data 


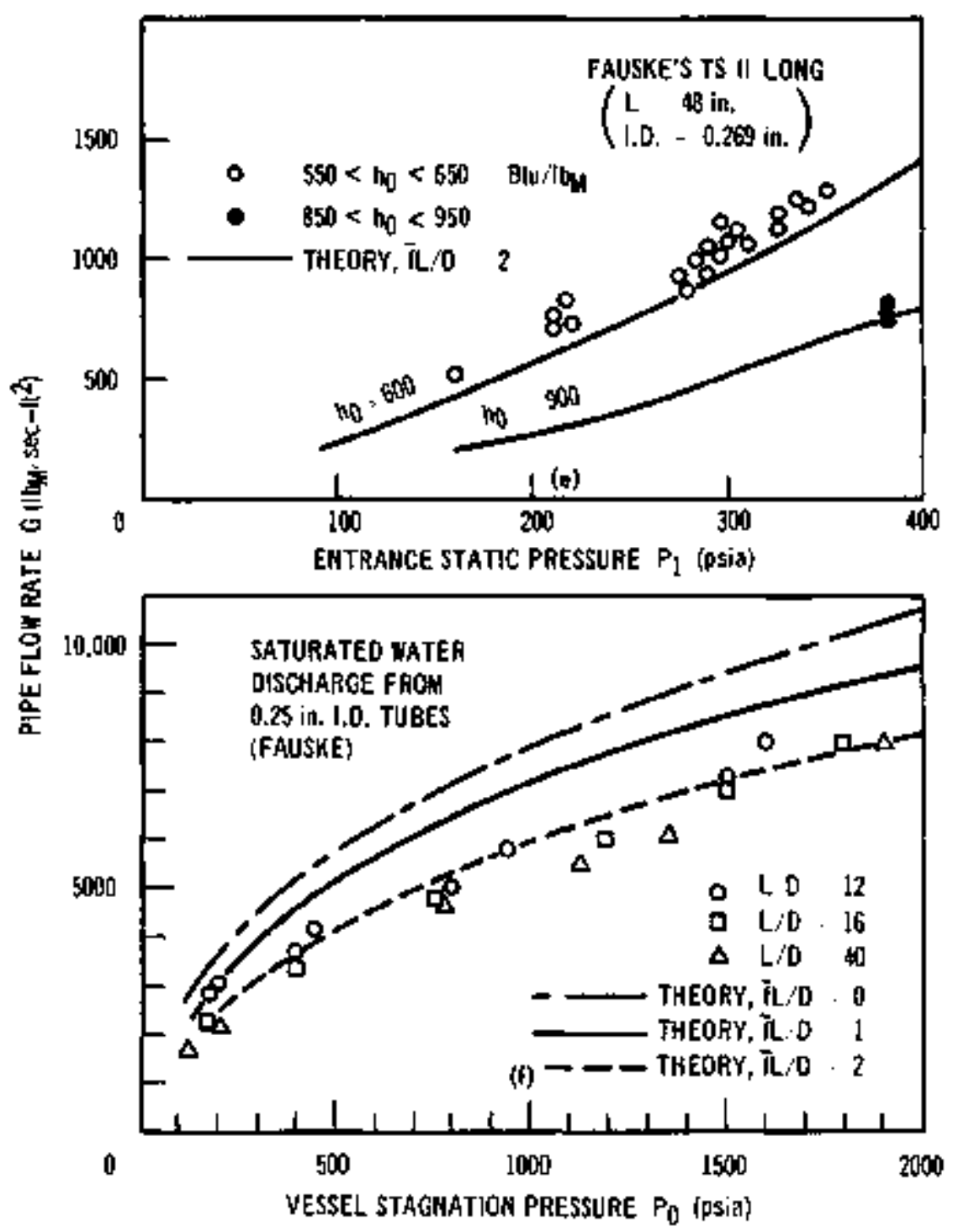

Fipure 3-1. Comparison with Fauske's Maximum Steam/Water Pipe Flow Data 
The present theory shows reasonable agreement wrth Fauske's data for test section TS IV short, Figure 3-1 (a) and (b), having an inside diameter of 0.125 inch. Theoretical flow rates tend to overpredict the data at lower stagnation enthalpies. The rounded value of $\overline{\mathrm{C}} \mathrm{L} / \mathrm{D}=4.0 \mathrm{correspond}$ to $\bar{f}=0.01$ and $L / D=384$. Test ralues of discharge quality ranged from 2, 0 to 43,0 percent.

Figure 3-1 (c), (d), and (e) shows Fauske's data for lower pressure in test section TS II long, having an inside diameter of 0.269 inch. Using $\bar{f}=0.01$ with $L / D=180$, a rounded value $\overline{\mathrm{S}} \mathrm{L} / \mathrm{D}=2.0$ was used for the theoretical comparison. Test discharge qualities are between 14.0 and 62.0 percent. Again, theoretical flow rates over-predjct the data at lower stagnation enthalpy. Best predictions are shown for $h_{0}$ around $500 \mathrm{Btu} / \mathrm{lb}_{\mathrm{m}}$. Under predicted flow rates are noted at $\mathrm{h}_{0}$ above $500 \mathrm{Btu} / \mathrm{lb}_{\mathbf{m}^{*}}$

Figure 3-1 (j) shows Fauske's most recent data for saturated water discharge from 0. 25-inch inslde diameter tubes. (6) The stagnation reservolr was a $35.0 \mathrm{ft}^{3}$ tank which contalned saturated water up to 2000 psia. Blowdowns were relatively slow so that stagnation pressure and enthalpy were nearly constant for each run. All tubes had sharp entrance sections and ranged in length from zero (oriflcel to 10 mches. Fauske concluded that equilibrium was approached at discharge in those teats when the tube length exceeded 3.0 inches. Shorter tobes exhibited non-equilibrium effects. Therefore, the present model was compared for tube lengths greater than 3.0 inches. The sharp-edged entrance pressure loss factor was assumed to be 0.5 single-phase veloclty heads. Using $\bar{f}=0.01$, values of $\bar{f} L / D$ for the varlous pipe lengthe ranige between 0.1 and 0.4 . Therefore, $\bar{f} \mathrm{~L} / \mathrm{D}$ was estimated bet ween 0.5 and 1.0 for these tests. Calculations are shown for the present model at $\overline{\mathrm{f}} \mathrm{L} / \mathrm{D}$ values of 0.0 and 1.0 . A calculation for $\overline{\mathrm{f}} \mathrm{L} / \mathrm{D}=\mathbf{2} .0$ is ghown for comparison and shows better ayreement with data.

Summarizing the comparison with Fauske's data, Figure 3-1 shows that the present model predicts maximum two-phase pipe flow rates to within \pm 30 . percent. This ts not surprising since Levy ${ }^{(10)}$ noted similar deviations in two-phase pressure drop predictions with his momentum exchange model.

The wall shear expression glven by Equation (s) is more applicable to lower quality flows. Therefore, flow rate over-predictions from the present model at lower $h_{0}$ are probably due to inherent overpredictions of maximum flows trom the energy model at lower values of $\mathrm{X}$. However, use of Equation (9) for wall shear would introduce pipe pressure drop errors al higher qualilies because of liquid entrainment and departure from an assumed annular flow pattern. Higher liquid entrainment would decrease effective viscostty near the wall, and consequently reduce wall shear for a given flow rate. Therefore, a bomewilat higher tlow rate would be expected than the present model esttmates at higher qualitles and stagnaIlon etthalptes.

\subsection{Correction for Higb Qualíty Flows}

Using Equation (5). ' $w$ wiven by Equation (9) can be written as follows for high quality flows:

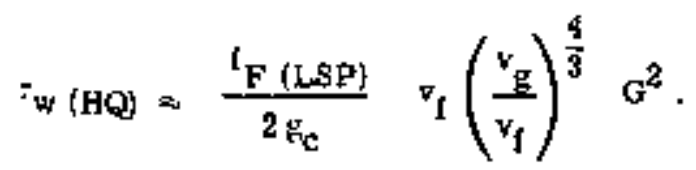


Equatlon (44), which contatins liquid properties, cannot be justtited for a case where liquid is almost totally absent. A better expresslon for wall shetar in bigh quality mixture flow would be

$$
\tau_{W(\mathrm{HQ})}=\frac{\mathrm{f}_{\mathrm{F}(\mathrm{MHO})}}{2 \mathrm{~g}_{\mathrm{C}}} \quad \mathrm{v}_{(\mathrm{WH})} \mathrm{G}^{2} .
$$

The tormulation of Equation (b) was used in the present model at all qualities, whereas Equation (45) would be preferred at higher values of $X$ or $h_{0}$. For hlgh quality flows, the triction factor in Equation (44) can be adjusted to a new value $f_{F(H Q)}$ to give approximately the same wall shear $\tau_{w(H Q)}$ as Equation (45) for a given flow rate G. Equating the two expressions for $\tau_{w}(\mathbf{W Q})$ *

$$
f_{F(H Q)}=f_{F(H+Q)}\left(\frac{v_{(\omega H O)}}{v_{f}}\right)\left(\frac{v_{i}}{v_{g}}\right)^{\frac{4}{3}}
$$

The present model therefore should give better predictions at higher stagnation enthalpy if $\bar{f}$ is approxlanated by

$$
\bar{f}_{(H Q)}=\bar{f}_{\text {(AMHO) }} \quad\left(\frac{v_{(\text {an⿴囗十) }}}{v_{f}}\right)\left(\frac{v_{f}}{v_{g}}\right)^{\frac{4}{3}} \text {; }
$$

2. g. a sujtable friction factor for estimating saturated vapor flow from the present model wotld be

$$
\vec{t}_{g}=\bar{f}_{(G S P)}\left(\frac{v_{f}}{v_{g}}\right)^{\frac{1}{3}}
$$

where $\left(v_{\mathrm{I}} / \mathrm{v}_{\mathrm{B}}\right)$ should be eva Juated at an average static pressure In the pipe.

\subsection{Comparison with Blowdown Tests}

The present blowcown prodel was compared with pressure suppression tests for: a full-scale. $1 / 112$ segment of the Bodega Bay atomic power plant, ${ }^{(15)}$ and a full-scale, $1 / 4$ B setitnent of the Humboldt Bay plant. (16) Figure 3-2 is a typlcal primary system schematic for elther series of tests. The model reactor vesgel initially contained saturated steam/water at 1250 psia. A double rupture disc assembly was used for the purpose of intiating blowdown. Vartous nozzles and orifices were usted to simulate specific blowdown flow areas. Transient vessel pressure traces were obtained for each test. Table 3-1 gives important data for all tests considered here. 


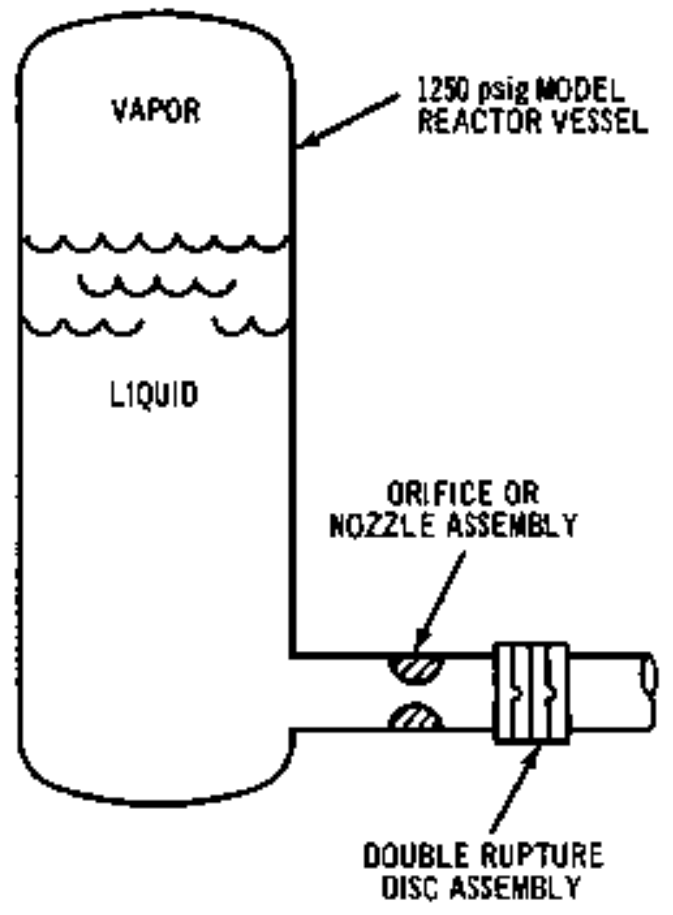

Flgure 3-2. Blowdown System for Bodega and Humboldt Pressure Suppression Tests 
TABLE 3-1

\section{SYSTEM DATA FOR BLOWDOWN TESTS}

\begin{tabular}{|c|c|c|c|c|}
\hline & Bodega - 40 & Bodega - 21 & Bodega - 16 & Humboldt - 22 \\
\hline Vessel Lnitial Pressure (psia) & 1250 & 1250 & 1250 & 1250 \\
\hline Saturation Temperature $\left({ }^{\circ} \mathrm{F}\right)$ & 572,4 & 572.4 & 572.4 & 572.4 \\
\hline Saturation Enthalpy (Bto// $\left.b_{n 1}\right)$ & 578.6 & $578+6$ & 578.6 & 578.6 \\
\hline Initial Water Temperature $\left({ }^{\circ} \mathrm{F}\right)$ & 537.4 & 572.4 & 572,4 & 572.4 \\
\hline Initial Water Enthalpy $\left(\mathrm{Btu} / \mathrm{lb}_{\mathrm{m}}\right)$ & 532.5 & 578.6 & 578.6 & 578.6 \\
\hline Initial Water Subcooling $\left(\mathrm{Btu} / \mathrm{lb}_{\mathbf{m}}\right)$ & 48. 1 & 0.0 & 0.0 & 0.0 \\
\hline Flashing Pressure (psia) & 940 & 1250 & 1250 & 1250 \\
\hline Nozzle Thrọat Area (sq in.) & B. 25 & 8. 25 & $\cdots$ & $\cdots$ \\
\hline Orifice Throat Area ( $\mathrm{Bq} \mathrm{in}_{+}$) & --- & $\cdots-$ & 20.6 & 0.95 \\
\hline Back Pressure (atm) & 1.0 & 1.0 & 1,0 & 1.0 \\
\hline Upstream Pipe Area (sq 3n.) & 115 & 115 & 115 & 26 \\
\hline
\end{tabular}




\section{S.5 Egtimation of Equivalent $\overline{\mathrm{L}} \mathrm{L} / \mathrm{D}$ for Bodepa Bay Tegt 40}

An eatimation of fi $/ D$ is required in the present theory for predicting blowdown teets. Such an estimation can be made by etther of two methods: a summation of atandard aingle-phase geometrle loss coefficients plus actual $\mathrm{f} L / \mathrm{D}$ components associated with the aystem tested; or calculation of an equifstent $7 \mathrm{~L} / \mathrm{D}$ from meseured irreversible presgure drop at a known cold water flow rate. The latter metbod was chosen. Although blowdown rate was not measured in any of the teste, a cold water tlow rate can be estirated in Bodeca Test 40 from the initial rate of vessel pressure drop. Test 40 initially contained $557^{\circ} \mathrm{F}$ water which was pressurized to $1250 \mathrm{psin}$ by introducing steam at the top just before blowdown. The gub-cooled water did not flash in the vessel until pressure dropped trom 1250 to 040 pain. Therefore, inttlal pressure drop was due to expansion of vapor to the vessel. Approximating the vapor by an ldeal gas, adiabatic presacure and volume clanges are related by

$$
d v_{g}=-\frac{v_{g}}{P_{0} \gamma} d P
$$

Vessel total volume is congtant. Therefore,

$$
\frac{d v}{d t}=-\frac{d v_{L}}{d t}
$$

The initlal blowdown rate ls then

$$
w_{L i}=-\rho_{L} \frac{d V_{L}}{d t}=\rho_{L} \frac{V_{L^{i}}}{P_{0 i}} \frac{1}{\gamma}\left(\frac{d P_{0}}{d t}\right)_{t} .
$$

Figure 3-3 (a) shows vessel pressure reduction for cold water blowdown before water saturation preseure was reached in the velisel. Initially, $\mathrm{dP}_{0} / \mathrm{dt} \approx-1350 \mathrm{psi} / \mathrm{sec}$, which led to an initial water blowdown rate of $\mathrm{W}_{\mathrm{Li}}=990 \mathrm{bb}_{\mathrm{m}} / \mathrm{sec}$, or $\mathrm{G}_{\mathrm{Ll}}=14,300 \mathrm{lb}_{\mathrm{m}} /$ eec-ft ${ }^{2}$ in the rozzle throat. Estimated nozzle throat static pressure dropped below water saturation pressure. However, vaporization probably did not occur; or it th did, the effect on flow rate was negliglble. Thls concluston was reached by comparing the cold water flow rate with calculations tor an oriflce and 1250 pel presgure differential.

An equivalent $\overline{\mathrm{L}} / \mathrm{D}=1.8$ based on nozule throat area was obtained by assuming all pressure drop occurred in an equivalent pipe with the same area, using the equation

$$
\frac{\overline{\mathrm{L}}}{\mathrm{D}}=\frac{2 \mathrm{~B}_{\mathrm{c}}\left(\mathrm{P}_{0}-\mathrm{P}_{\mathrm{R}}\right) \rho_{\mathrm{L}}}{\mathrm{G}_{\mathrm{Ll}}{ }^{2}}
$$

However, expansion losses downstream trom the nozzle are included in this calculation, Such expansion losses do not affect flows which choke in the nozzlo throat. Subtrecting an expansion lose of 1.0 veloctty head wave a rounded value of $\overline{\mathrm{f}} \mathrm{L} / \mathrm{D} \approx 1.0$. Thls value was applied directly to Bodega Test 21 , which had a saturated blowdown with the same nozzle used in Test 40. 


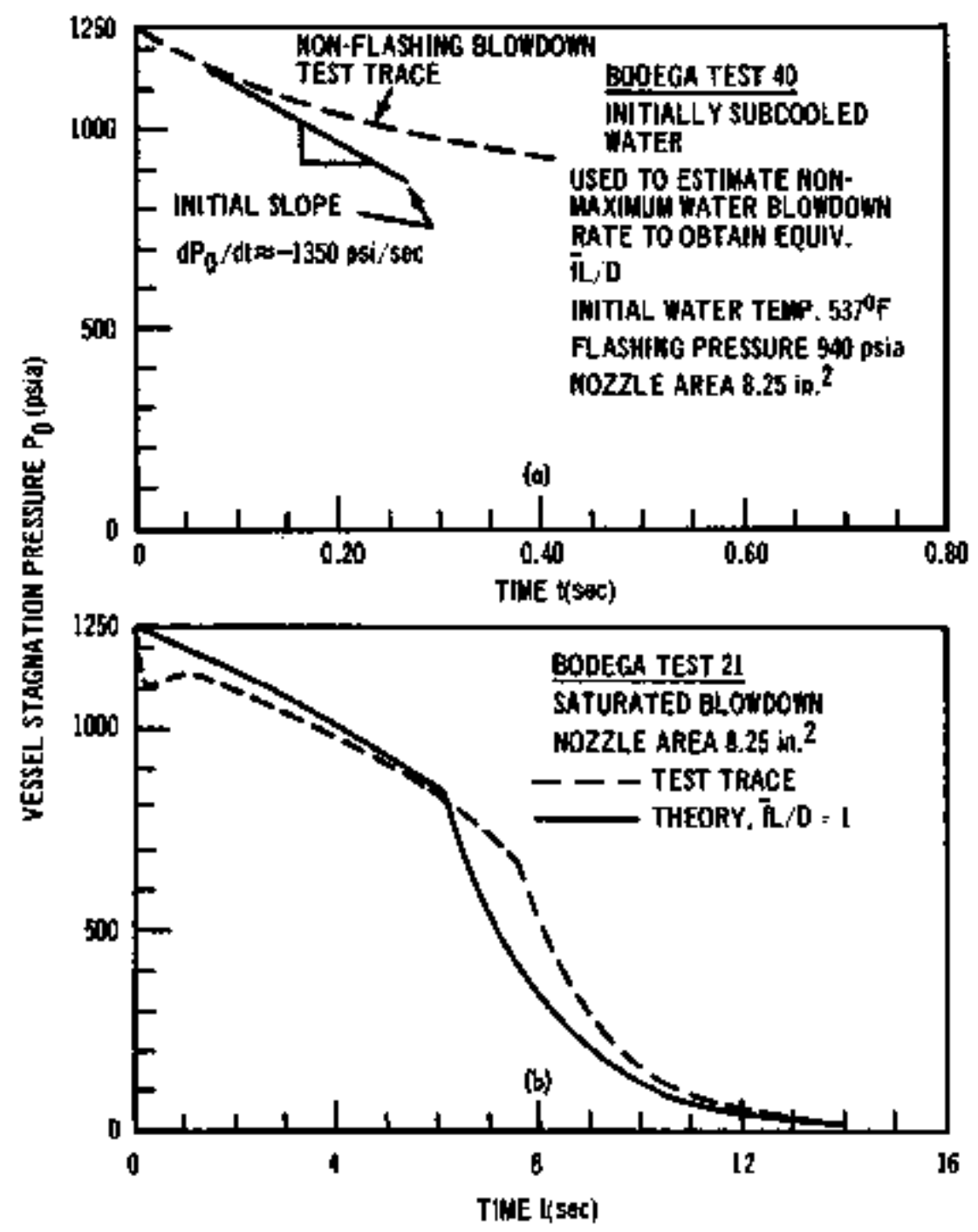

Flgure 3-3. Comparison with Blowdown Tests 


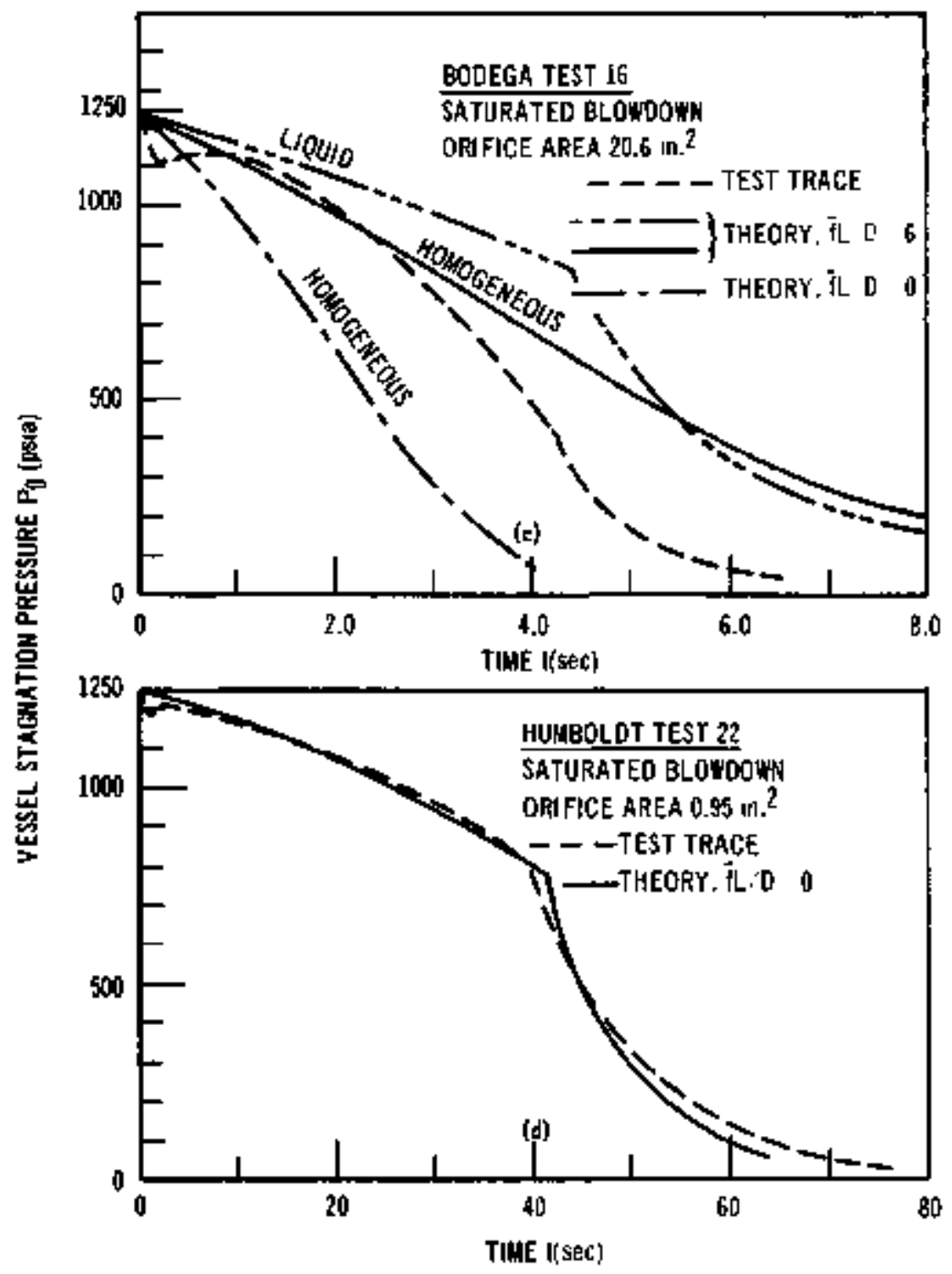

Figure 3-3, Comparison with Blowdown Tests 


\section{6 Comparison with Bodega Test 21}

The present motel uting $\overline{\mathrm{f}} / \mathrm{D}=1.0 \mathrm{Is}$ compared whth Test 21 in Figure 3-3 (b). There te a gharp initial dip in test pressure which essentfally recovers in 1.0 second. This characteristic appeared in all saturated blowdown tests and is not shown by the present model. It may be explatned by a combination of two effects: initial discharge of slightly sub-cooled liquld, not restricted by a two-phase mechanism; and the delay time for vapor bubbles to form and expand in llguid.

Also, the experimental traces show a "knee," or sudden therease in pressure drop rate. The theoretical liquld blowdowns in Figure 2-7 alsa show a knee when saturated water blowdown 18 followed by saturated vapor blowdown. Thls is important evidence regarding the nature of steam/water behavior in the vensel during blowdown. The present model was applied to Bodega Test 21 by assuming complete . water expulsion followed by vapor expulston. This is reasonable since blowdown proceeded from a low point on the vessel. The theoretical knet in Figure $3-3$ (b) is seen to occur at a pressure of 850 peia where the trace indicates the knee at $\mathbf{6 7 5}$ psia. Therefore, vapor must have formed faster than $\mathrm{tt}$ could separate from the Irquid during blowdown, prolonging appearance of the actuat knee. Vapor entrainment in liquid gives higher stagnation enthalpy near the break, the effect of which is two-fold at a given stagnation pressure: it decreases maximum flow rate (Figure 2-4), and it increases inttial pressure drop rate (Fisure 2-7). This points out the importance of Itquid/vapor action in a vessel during blowdown, which is another problem.

\section{7 Compartioon with Bodega Test 16}

One would expect the knee in Figure 3-3 (b) to occur earlier in time and at tower pressures ab the Dozzle throat area increased.

Bodega Test 18, Figure 3-3 (c), is simllar to Bodego Test 21 except for an increased blowdown area, and an orlfice replacling the nozzle. Although the knee is still evident, the blowdown area increase of almost 3 times that in Test 2 I nearly caused its disappearance. A large nozzle might cause such rapid vapor formation that a nearly homogeneous liquid/vapor mixture would fill the vessel, and the knee would disappear altogether.

A remark is in order concerning the estimation of $\overline{\mathrm{J}} \mathrm{L} / \mathrm{D}=6$, used for comparison with Bodega Test 16. It was found that Bodega Test 17 (not shown) was nearly identical to Bodega Test 21 except that an oriflce was used instead of a nozzle. Blowdown areas were the same in each case, and the prossuretlme characteristles were nearly tdentical. It was concluded that exchanging an orifice for a nozale caused negligible effects on flow rate for these blowdown tests, upstream irreverstbilities boing unaffected. Blowdown area evidently is the tmportant variable, Therefore, $\mathfrak{i L} / \mathrm{D}=1$ in Test 21 was slmpiy increased by the square of the throat area ratio in Tests 18 and 21 .

It is unlfkely that a high concentration of zapor would occupy the vessel lower region during blowdown while liquid was still present. Therefore, steam/water action in the vessel for all Bodega and Humboldt tests should lie somewhere between: (1) a homogeneous mlxture ftlling the versel; and (2) completely separated phases with water occupying the vessel lower region until fully expelled. The present model was therefore used to estimate both liquid and homogeneous blowdowns for Bodega Test 16. Both theoretical bloudowns are seen to be too olow in Figure 3-3 (c). This leads to the conclusion that the estimated $\overline{\mathrm{I}} \mathrm{L} / \mathrm{D}=6$ is 100 high. A theoretjcal curve for $\overline{\mathrm{I}} \mathrm{L} / \mathrm{D}=0$ and a homogenous system are shown for comparison. It clearly estimates too fast a blowdown. 
Admlttedly, the present model may encounter dlfflctily if applied to cases with predominant or complex geometric pressure loss effects.

\section{8 Comparison with Gumboldt Test 22}

Humboldt Test 22 had 2 very small blowdown area equal to $0.95 \mathrm{gq}$ in. Upstream velocities in the 26-sq-in. pipe could not exceed 10 fps, based on cold water ortfice flow calculatlons from 1250 psia. Therefore, geometrlc and iriction pressure losses between the vessel and orifice could be neglected. The value of $\mathrm{f} L / D=0$ was used in the present theory to compute a liquid biowdown followed by vapor. The result is shown in Figure 3-3 (d). Agreement to very good.

Fauske ${ }^{(B)}$ confirmed by his tests that saturated water flow tirough an orifice did not flash until it cleared the apertura. However, the water flow rate in Humboldt Test 22 apparently was restrtcted by a two-phase mechanism. This implies that a small fraction of vapor was entrained in liquid near the or lfice due to homogereous boilting. 


\section{APPENDIX A}

\section{NOMENCLATURE}

\section{Major Symbols}
A $\quad$ Area, $\mathrm{ft}^{2}$
D $=$ Hyöraulic diameter $4 \mathrm{~A} / \mathrm{P}_{\mathbf{W}^{*}}$ it
E = Internal energy, Btu
$\mathrm{E}^{*} \quad$ = Internal energy fraction defined by Equation (36), dimensionless
e $\quad=$ Specific internal energy, $\mathrm{Bku} / \mathrm{lb}_{\mathrm{m}}$
$t_{F} \quad=$ Local Fanning friction factor. dimension]ess
f - Local Darcy friction factor; $\left(I=4 \mathrm{f}_{\mathrm{F}}\right.$ for circular pipes), dimenstonless
$\left\{\begin{array}{l}f_{1}, f_{2} \\ f_{3}, f_{4}\end{array}\right\}=$ Functions defined by Equations (16) through $(19)$
$\mathrm{G}=$ Mass flow rate per unit area, ahbreviated "maks flow rate, ${ }^{1+} \mathrm{lb}_{\mathrm{m}} / 8 \mathrm{sec}-\mathrm{ft}^{2}$

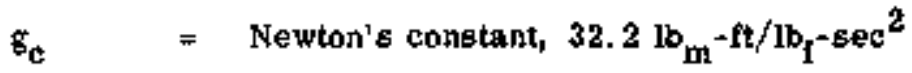
h $\quad$ Specific enthalpy, Btu/lb
$\mathrm{J}=$ Mechanical equi valent of heat, $778 \mathrm{ft}-1 \mathrm{~b}_{\mathrm{f}} /$ Btu
$\mathrm{J}^{\prime}=\mathrm{J} / 144,5+403 \mathrm{ft}^{3}-1 \mathrm{~b}_{\mathrm{I}} / \mathrm{tn}^{2}-\mathrm{Btu}$
K - Slip ratio, dimensionless
L $\quad=$ Pipe length, $\mathrm{ft}$
$\ell \quad$ a Downstream distance from pipe inlet, $\mathrm{ft}$
$\mathrm{M} \quad$ Mass, $\mathrm{Ib}_{\mathbf{m}}$
$M^{*} \quad=$ Mass fraction defined by Equation (34), dimensionless
P = Pressure, psia
$P_{w} \quad=$ Wetted perimeter, ft.
$\mathrm{R}_{\mathrm{eL}} \quad-\quad$ Liquid Reynold's number defined by Equation (10), dimensionless
$8=$ Speciflc entropy, Btu/ $/ \mathrm{b}_{\mathrm{m}}{ }^{\circ} \mathrm{F}$
$t^{*} \quad=$ Dimensional time defined by Equation (37), $\mathrm{ft}^{2}-\mathrm{sec} / \mathrm{lb} \mathrm{m}$
u $=$ Velocity. $\mathrm{tt} / \mathrm{sec}$
$\mathrm{V}=$ Volume, it $^{3}$
$\mathrm{v}=$ Specific volume, $\mathrm{rt}^{3} / 1 \mathrm{~b}_{\mathrm{m}}$
$\mathrm{W}=$ Mass flow rate, $\mathrm{lb}_{\mathrm{m}} / \mathrm{sec}$
$\mathrm{X} \quad=$ Quaitty (vapor mass flow traction), dimensionless 


\section{Major Symbols (Continued)}

$\alpha$ - Vapor volume fraction, dimensionless

$\Gamma=$ Function defined by Equation $(23), \mathrm{in}^{2} / \mathrm{lb}_{f}$

$\gamma \quad=$ Isentropic exponent, dimensiontess

a = Dynamtc viscoslty, $1 b_{m} / t$-sec

$\rho=$ Density, $\mathrm{lb}_{\mathrm{m}} / \mathrm{ft}^{3}$

$\tau_{\mathrm{w}} \quad=$ Wall shear stress, $\mathrm{lb}_{\mathrm{f}} / \mathrm{rt}^{2}$

$\mathrm{a}=$ Momentum flow rate, $1 \mathrm{~b} \mathrm{~m}-\mathrm{ft} / \mathrm{sec}^{2}$

\section{Subseripts}

E - Blowdown escape ralue

f $\quad=$ Saturated liquid

$f_{g} \quad \therefore$ Vaporization

B = Saturated vapor

GSP $\quad$ Cas in single phase flow

HQ $=$ High Quality

1 = Initial ralue

L $=$ Liquid

LSP $\quad-\quad$ Liquid in single phase tow

$M \quad=$ Property at maximum flow rate

m. Mixture

we $=$ High quality mixture

0 $\quad$ - Value at stagnation condtion

R $\quad$ Receiver

$1 \quad$ I Pipe entrance

$2=$ Pipe discharge end

Special Symbola
(
( $)^{t}=$ Derivative with respect to pressure 


\section{REFERENCES}

t. D. W. Ealett. "Two-Phase Critical Flow of Steam/Water Mixtures," Dissertation, University of Waslitngton, 1959.

2. H. Fusske, "Contribution to the Theory of Two-Phase. One Component Critical Flow," ANL-6633, U. S. AEC Research and Development Report, TID-4500. 18th Ed. . Oetober, 1962.

3. J. E. Moy, "Critical Discharges of Steam/Water Mixtures." MS Thesis. University of Minnesota, 1955.

4. F. R. Zaloudek, "The Low Pressure Critical Discharge of Steam/Water Mixtures trom Pipes " HW - 68934 Rev., March 1061.

5. F. R, Zaloudek, "The Critical Flow of Hot Water Through Short Tubes," HW - 77594, TLD-4500, 21st Ed., May. 1963.

6. H. Fauske, "The Discharge of Saturated Water Through Tubeg," A I Ch E Preprint 30, presented at the Seventh National Heat Transier Conference, Cleveland, Ohio, August 9 to 12.1984.

7. S. Levy. "Predtction of Two-Phase Critical Flow Rate." Journal of Heat Transter, Trans. ASME, Series C, Vol, 87, p, 53.

8. F. J. Moody, "Maximum Flow Rate of a Single Component, Two-Phase Mlxture," Journal of Heat Transfer, Trans. ASME, Serieg C. Vol, 87, p. 134.

9. R. C. Martinelli and D. B. Nelson, "Predtction of Pressure Drop During Forced-Circulation Boiling of Water," Trans. ASWE 70, 1946.

10. S. Levy, "Steam - Slip - Theoretical Predittion from Momentum Model, " Journal of Heat Transfer, Trans, ASME. Series C. Vol. 82, p. 113, 1960.

11. S. M. Ztvi, "Estimation of Steady-State Vold Fraction by Means of the Principal of Minimum Entropy Production, Journat of Heat Jransfer, Trans. ASME, Series C, Vol. 86, p. 247.

12. A, H. Shapiro, The Dynamics and Thermodymamics of Compressible Fluid Flow, Vol. 1. The Ronald Press, New York, N. Y., 2953.

13. J. H. Keenan and F. G. Keyes, Thermodynamic Propertles of Steam, John Wlley t Sons, Inc., New York, N. Y. + First Edition, 1955.

14, L. F, Mogdy, "Friction factors for Pipe Flow," Trans. ASME, Vol. 66, No. 8, November, 1944, p. 671 . 


\section{REFERENCES (Continued)}

15. "Preliminary Hazarde Summary Report, Bodega Bay Atomic Park Unit No. $1{ }^{+1}$ Paciflc Gas $\&$ Electric Company, December 1962.

16. C. H. Robbins, "Tests of a Full scale 1/48 Segment of the Humboldt Boy Pressure Suppresgion Containnent," GEAP-3596, November 1960.

\section{ACKNOWLEDGMENT}

Particular gratitude is expressed to D. E. Whlliams for obtaining machine solutions from which Ilow rates in Figure 2-4 were obcained. R. E. Allen helped consjderably in calculations for Figure 2-7 and preparation of graphs. 


\section{INTERNAL DISTRIBUTION LIST}

R. E. Alien

J. O. Arterburn

A. S. Bartu

H. A. Brammer

A. P. Bray

J. F. Cage, Jr.

J. T, Cochran

K. P. Coben

W. H. Cook

F. E. Cooke

J, E. Corr

R. L. Crowther

D. C. Ditmore

C. P. Dunlap

v. A. Elliott

w. H. Ellis

G. W. Fitzsimmons

L. E. Fosler

W. D. Gilbert

P. Greebler

R. G. Hamilton

M. A. Head

J. M. Healzer

F. K. Herrick

C. W. Hewitt

J. J. Hogle

J. E. Hench

J. W. Holtzclaw

P. W. Ianni

D. H. Imholf

E. Janssen

C. B. Johnson

W. R. Kanne

F. E. Tippets

General Electric Co.

Evendale Plant

Cincipnati, Dhio
J. E. Kjemtrup

A. A. Kudirka

M. J, Larocco

R. B. Lemon

S. Levy

D. J. Ltffengren

M. G. McBride

L. H. McEwen

R. J. McWhorter

R. H. Moen

C. E. Morris

D. R. Nelson

R. O. Niemf

J. F. O'Mara

R. T. Pennington

E. E. Polomik

E. P. Quinn

R. B. Richards

L. S. Richardson

G. F. Rieger

C. H. Robbins

G. M. Roy

w. A. Sutheriand

S. W. Tayart

P. Thompson

F. E. Tippits

T. Trocki

D. E. Williams 1450 So. Albion Street Denver 22, Colorado

B. Wolre

J. E. Wood

N. Zuber

G. E. Advanced Tech. Laboratory Schenectady, New York

APED Library (5)

VAL Lilsrary (3) 


\section{EXTERNAL DISTRIBUTION LIST}

J. N. Batch

Hanferd Atomte Products Operation

1707 D Building:

Rkchland, Washington

H. Fauske

Argonne National Laboralory

Arenone, Illinois

B. Johnson

Batelle - Northwest

Richland, Washington

Prof. G. Leppert

Stanford University

Stanjord, California

K. Neusen

Allis-Chalmers Mf: $\mathrm{Co}$.

Atomic Enerky Division

Greendale, Wisconsin

C. E. Parks (B \& W)

1201 Kemper street

Lynchburg, Virginia

Prof. V. E. Schrock

University of Callfornia

Berkeley, Calsfornta

F、 Zaloudek

Batelle - Northwest

Richland, Washington 
SAW IASE, CALIFORIIIA

\section{TECHNICAL INFORMATION SERIES}

TITLE PRGE

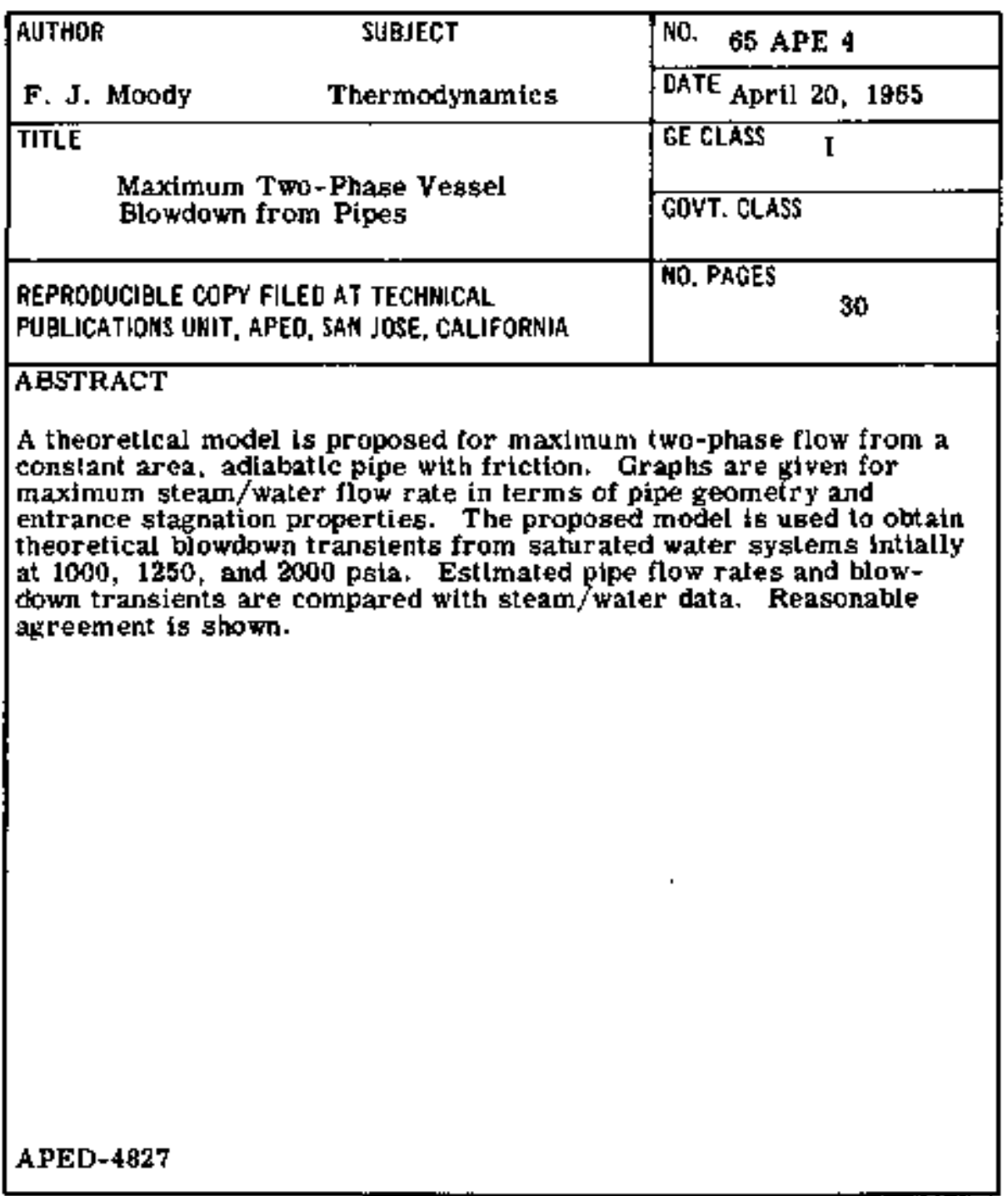

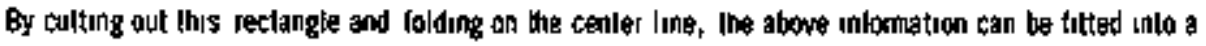
slandard card file.

For IIsI ol conlents - drawings, pholos, elc. and for distribulion sext nege (FH-\$10-2)

JOB RIJMBER _2342-TIO-2

INFORALATON PREPAREO FOR Atamic. Powker Egutbment Department

TESTS MAOE BY

COUNTERSJGNEO

SECTION

BUHLOIHG AND ROOW HO.

LOGATION 